DEPARTMENT OF COMMERCE BUREAU OF FOREIGN AND DOMESTIC COMMERCE

E. E. PRATT, Cbief

SPECIAL AGENTS SERIES-No. 96

\title{
DYESTUFFS FOR AMERICAN TEXTILE AND OTHER INDUSTRIES
}

\section{BY}

THOMAS H. NORTON

Commercial Agent of the Department of Commeres

WASHINGTON

GOVERNMENT PRINTING OFFICE 


DEPARTMEN T OF COMMERCE BUREAU OF FOREIGN AND DOMESTIC COMMERCE

E. E. PRATT, Chief

SPECIAL AGENTS SERIES-No. 96

\title{
DYESTUFFS FOR AMERICAN TEXTILE AND OTHER INDUSTRIES
}

\author{
BY \\ THOMAS H. NORTON \\ Commercial Agent of the Department of Commerce
}

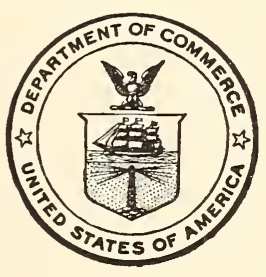

WASHINGTON

GOVERNMENT PRINTING OFFICE

1915 
ADDITIONAL COPIES

OF THIS PUBLICATION MAY BE PROCURED FROM THE SUPERINTENDENT OF DOCUMENTS

GOVERNMENT PRINTING OFFICE WASHINGTON, D. C.

AT

10 CENTS PER COPY 


\section{CON T E N TS.}

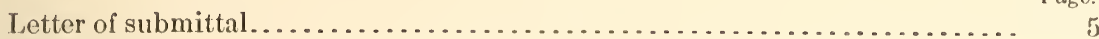

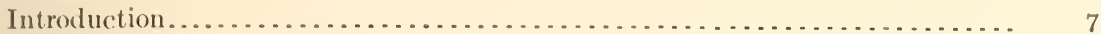

Dyestuff situation in the United States............................. ${ }^{2} 12$

Dyestuffs used in the United States......................... 12

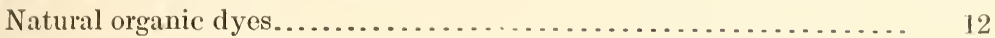

Importation of natural organic dyes..................... 14

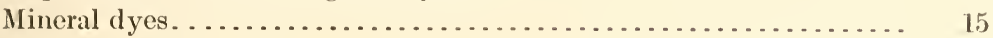

Artificial organic dyes. . . . . . . . . . . . . . . . . . . . . . 15

Domestic manufacture of artificial dyestuffs............... 16

Foreign sources of artificial dyestuffs....................... 17

Economic effects of dependence upon a single foreign source....... . 17

Increased cost of coal-tar dyes. .......................... 18

Outlook for the immediate future........................ 18

Alternatives in case of a dyestuff famine................... . 19

Outline of the coal-tar chemical industry . . . . . . . . . . . . . . . . 20

Coal-tar dye industry in the United States...................... 21

Slow development of the American industry................ 21

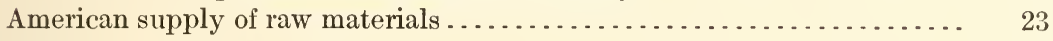

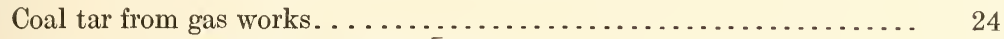

Coal tar and benzol from coke works. ..................... 24

Present production of crude tar products.................... 26

Price movement of American coal-tar crudes. . . . . . . . . . . . . . . 28

Position of the American tar distiller........................ 28

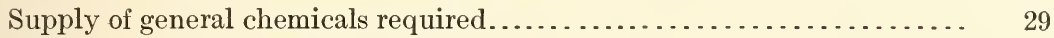

The German coal-tar dyestuff industry ......................... $\quad 30$

Trade in crudes and intermediates........................... 31

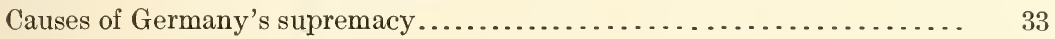

Research the chief cause............................... 34

German industry, capital, dividends, etc.................. 34

Geography of the German industry . . . . . . . . . . . . . . . . . 35

Relations between companies.......................... 35

Equipment of plants....................................... 37

Wages in the German factories............................. 37

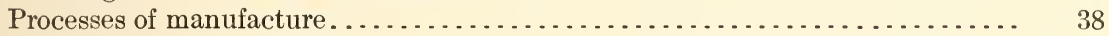

Uniformity of product....................................... 40

Typical phases............................................ 40

Illustrative outlines........................................ 41

Alizarin, naphthol yellow, magenta...................... 41

Hydroquinone and synthetic indigo..................... 42

The ketone dyes.................................. 44

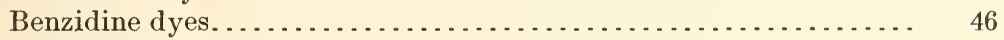

Tolidine and allied dyes............................. 48

Patents in the German industry............................. 48

American attitude toward the German industry...................... 51

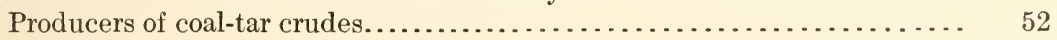

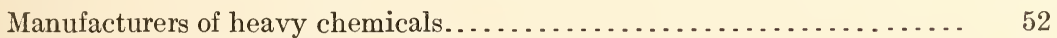

Manufacturers of artificial dyestuffs.......................... 52

Consumers of artificial dyestuffs............................. 53

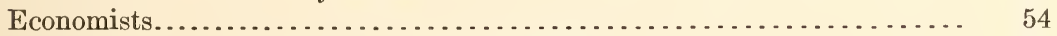

American Chemical Society, New York section .................. 54

Establishment of an American industry........................... 55

The problem in England and France.............................. 56

Summary .................................................. 57 



\title{
LETTER OF SUBMITTAL.
}

\author{
Department of Commerce, \\ Bureau of Foreign and Domestic Commerce, \\ Washington, March 20, 1915.
}

SrR: There is submitted herewith a report by Commercial Agent Thomas H. Norton on dyestuffs for American textile and other industries. This report was called for by a resolution of the Senate, under date of January 26, 1915. It presents fully the nature of the dyestuffs used by American industries and the sources of supply, showing the limited extent of the domestic manufacture and the general dependence upon foreign-made dyes. The predominance of Germany in this field is shown, and the reasons for this situation are detailed. All factors connected with the creation of a self-contained, independent, American coal-tar chemical industry are given in full, and the problems involved by a threatened cessation of the present foreign supply are considered.

Respectfully,

To Hon. William C. Redfield,

E. E. Pratt, Chief of Bureau. Secretary of Commerce. 



\section{DYESTUFFS FOR AMERICAN TEXTILE AND OTHER INDUSTRIES.}

\section{INTRODUCTION.}

Under date of January 26, 1915, the Senate of the United States passed the following resolution:

Resolved, That the Secretary of Commerce be, and he is hereby, directed to inform the Senate as fully as possible as to the facts relating to the supply of dyestuffs for American textile and other industries, the sources of such supply, the extent and nature of the supply, the movement of prices, the available materials for the manufacture of such supplies in this country, the possibilities, if any, as to the stoppage of such supply by reason of the existing European war, and any and all such other facts as will bring the existing conditions in the aniline color industry fully to the knowledge of the Senate.

In response to this resolution, the Secretary of Commerce communicated to the Senate, under date of February 20, 1915, the following preliminary report, which summarizes the main facts and outlines the scope of the full report as here given.

\section{PRELIMINARY REPORT.}

Numerous American industries are closely dependent upon the use of dyestuffs. To the great textile branches they are almost as essential as their supplies of vegetable or animal fibers. The same condition exists in the paint, varnish, and ink trades, the paper industry, the feather and leather trades, and a group of minor industries. Dependent upon the products of these industries are a host of other branches, all users of textiles. The old-time natural dyestuffs, such as indigo, madder, cochineal, orchil, fustic, and a score more, have no longer an extended use, with the exception of logwood, which still plays a valued auxiliary rôle. The same is the case with mineral colors, with some inconsiderable exceptions, such as Prussian blue in silks and iron buff in khaki.

Artificial dyestuffs, derived from coal-tar products, have displaced nearly all rivals, combining qualities of fastness, ease of application, brilliancy, variety of shades, etc., utterly unknown to the former generation of dyers.

\section{EFFECT OF WAR ON DYESTUFF CONSUMERS.}

The American consumption of artificial dyestuffs has attained an annual value of $\$ 15,000,000$, and grows steadily.

It is supplied partly by a domestic production valued at about $\$ 3,000,000$. This apparent domestic production is based chiefly upon the use of foreign materials-half-made or nearly completed color compounds. But a small portion is made from American crude coaltar compounds. 
The great bulk of the artificial dyestuff supply comes from Europe. The average imports are: From Germany, $\$ 7,850,000$; Switzerland, $\$ 910,000$; Great Britain and others, $\$ 370,000$; total, $\$ 9,130,000$.

Since August 1, 1914, in consequence of the outbreak of hostilities in Europe, this foreign supply has been interrupted and constantly threatened with nearly complete cessation. Until the present date, German makers have been able to supply a considerable proportion of the normal demands of their customers, but not entirely. Some important dyes are totally unobtainable. Prices have mounted from 25 to 50 per cent on such dyestuffs as can be delivered. The imports may cease any day through inability to make shipments, on account of maritime dangers, or what is more probable, through the military necessity of commandeering the available supply of the chief coaltar crude material, benzol, for use as a motor fuel, or diverting the limited supply of nitric acid-the chief chemical used in color manufacture - to the manufacture of explosives.

The multitude of users of dyestuffs in the United States have been crippled in various ways, forced to change designs, or abandon certain products, or to revert to a temporary use of natural dyestuffs, with all the accessory readjustment and revolution in dyeing processes. On every hand there is difficulty in meeting contract specifications and in making definite plans and agreements for the future. The importation of dyewood has quickly increased. It is now four times as great as in normal times. Prices of these dyewoods have mounted. Fustic, for example, has doubled in price.

The four American establishments making artificial dyestuffs have done their best to meet the emergency by enlarging the ordinary output. They have been crippled by the difficulties or impossibility of securing half-manufactured materials from abroad or crude materials at home. Some large consumers of dyestuffs have erected emergency plants and make the colors they absolutely need, but at considerable cost.

\section{DOMINANCE OF THE GERMAN INDUSTRY.}

In all this annoyance, loss, and uncertainty why do we not have an American coal-tar chemical industry, capable of meeting the Nation's demands, self-contained and independent of foreign control, utilizing our native raw material ?

A careful analysis of the situation shows that not only is the American'supply and the limited American production of coal-tar dyestuffs completely dominated by the German industry, but that this is the case throughout the world. Even countries such as Great Britain and France, with ample supplies of crude material and highly developed industrial power, are in the same condition as the United States.

In 1913 the total consumption of artificial dyestuffs in the world had attained a value of over $\$ 92,000,000$. Germany furnished 74 per cent of the entire amount and over one-half of the materials needed to make the remainder. The only country, in addition to Germany, manufacturing dyestuffs in any noteworthy manner for the world's markets is Switzerland. That country relies, however, for its crude and half-manufactured materials chiefly upon German sources. The dominance of Germany in the dyestuff production and 
commerce of the entire world is so marked, and inherently of such potential might, that it does not hesitate to make itself felt whenever and wherever an effort is made toward emancipation from its control. The methods used are those often associated with the working of great industrial corporations in various lands and now affectively checked by legal enactment in the United States. In tho case of the German coal-tar chemical industry, the field is international and its operations are unchecked by law. Its influence has been felt at once in our own country when efforts to manufacture intermediate compounds or finished dyes threatened in any way the interests of the German production and trade.

\section{ADVANTAGES POSSESSED BY GERMAN MANUFACTURERS.}

The coal-tar chemical industry includes not only the manufacture of dyestuffs, but of a number of valuable medicinal preparations, and of various high explosives. It is based upon the use of crude compounds present to a small extent in the tar obtained in the destructive distillation of coal in gas works and coke ovens. These 10 crude compounds-benzol, carbolic acid, anthracene, etc.-are separated from some 145 other substances present in tar, by fractional distillation. 'This is the work of the tar distiller. From the 10 crudes, nearly 300 more complex compounds, none of them dyes, are produced by highly refined and complicated chemical and mechanical processes, involving in most cases a number of complete chemical transformations. These serve as the materials for the manufacture of about 920 dyestuffs now in current use.

In the case of Germany, the domestic supply of "crudes" is amply sufficient. 'The color factories make all of the 300 intermediates required for Germany's own industry and a large share of those used in the very restricted production of other lands.

The industry has been chiefly developed by the inventive power of German chemists, combined with a wealth of technical skill and keen business management, scarcely equaled in the history of any other branch of manufacture. The 21 German companies engaged in the dyestuff manufacture have a nominal capital of over $\$ 36,700,000$ on which dividends average 22 per cent. Actual profits often reach 50 per cent. The great excesses have been devoted to new construction. It is the most remunerative industry in the Empire, the one most solidly and formidably intrenched, the one of which the nation is most proud as showing the triumph of science applied to industrial purposes, and the one illustrating most strikingly the ability to win and maintain international supremacy in a given field.

\section{ABUNDANCE OF AMERICAN RAW MATERIAL.}

In the United States the supply of coal tar is ample, sufficient to provide in abundance all of the crudes required for the manufacture of the dyestuffs consumed in the country. 'The amount of valuable by-products not yet recovered in our present coking plants amounts to $\$ 75,000,000$ annually. With adequate provision to save all the benzol and tar liberated in American coke ovens, enough of the 10 crudes could be secured to more than cover the world's consumption in making artificial dyestuffs. 
If a commercial demand is present, American tar works can quickly provide all of the crudes needed, practically as cheaply as in Europe. In the manufacture of intermediates the production is restricted to four or five compounds, and these cover about onequarter of the needs of American color works.

Our manufacture of heavy chemicals is well developed, able to expand rapidly, and supply all needed chemicals for the production of intermediates and their transformation into finished dyes.

The four establishments devoted to the production of dyes supply nearly 100 different colors, largely, however, as already stated, by "assembling" nearly finished products of foreign origin. These American firms are bold and enterprising, commanding about $\$ 3,000,000$ capital, evidently doing the best they can under existing conditions to build up a national industry.

Investigation shows that their advance, beyond certain limits, in the manufacture of either intermediate or finished dyes is persistently checked and prevented by the united action of German producers in underselling. The entire German color industry is so completely organized and accustomed to act as a unit in furthering the general interests, at home and abroad, that little success in facing their determined opposition has heretofore been obtained.

The present crisis has evoked deep interest on the part of all concerned - tar distillers, manufacturers of chemicals, manufacturers of dyestuffs, the many users of the same, and American economists in general-as to how the problem can be settled. There is no question but that our coke interests are ready to multiply their recovery plants for the production of benzol and tar, if a permanent market is assured. There is no question of the readiness of tar distillers to enlarge their plants for the production of an ample supply of the needed crudes if a continued demand is certain. American chemical works and American manufacturers of dyestuffs are ready to embark capital and experience in building up a distinctly American coal-tar chemical industry, using entirely American crudes and intermediates, provided there is adequate legislative prohibition against both "dumping" or unfair restraint of American trade by the arbitrary action of foreign monopoly permitted by foreign law and not as yet forbidden by our own. Domestic makers assert their ability to make at once over 90 per cent of the dyes now consumed in the United States, which are now patent-free, and state that the remaining tenth will soon be freed from patent restriction.

\section{WHAT THE AMERICAN INDUSTRY REQUIRES.}

There seems to be a consensus of opinion that any rapid development and evolution of the dyestuff branch, on a scale commensurate with the Nation's needs, present and prospective, can be assured only on the basis of an effective law preventing that action toward control of our markets by a foreign monopoly which is now prohibited to a domestic monopoly. Some of the largest manufacturers have personally informed the department that what is needed is not a tariff change, but laws placing a foreign monopoly on the same basis as an American one.

American economists feel that the present crisis offers the most favorable moment to decide upon a policy with regard to this one 
important industry, whether it is to be firmly rooted in American soil or whether the dependence upon a foreign source is to continue indefinitely. It is pointed out that each year elapsing increases in geometrical ratio the difficulties attendant upon any attempt to create a self-contained American dyestuff industry. Further, it is claimed that it is the only highly organized industry not yet brought on a broad and generous scale within the cycle of American economic activity.

In England and France the textile and other branches have insisted that the national industries must be permanently freed from dependence upon a foreign source for one of the vital needs of the most varied manufactures. Within a fortnight the group of French chemists intrusted with the problem claim that they have satisfactorily solved all difficulties in the way. During the same period the necessary steps have been taken in England, where the Government has provided for the organization of a national company to create an independent dyestuff industry, contributing nearly $\$ 2,000,000$ to its capital, and granting at the same time $\$ 500,000$ for the requisite research laboratory. 


\section{DYESTUFF SITUATION IN THE UNITED STATES.}

There is a large and steadily growing consumption of dyestuffs in the United States required in a variety of industries. The most important of these industries are: Textiles - cotton, silk, woolen, etc.; paints and pigments; varnishes; inks; leather articles; feathers.

A great variety of industries, in addition, are closely dependent upon the above for all that concerns color effects. Prominent among these are the printing trades; automobile and carriage manufacture; implement manufacture; paper trade; soap trade; upholstery trade; millinery, dressmaking, etc.

Further, a notable and increasing number of preparations made from by-products and accessory. products of the manufacture of artificial dyestuffs are now used in photography, medicine, the production of high explosives, and the manufacture of artificial perfumes. Economically these are very closely interlocked with the dyestuff industry.

Directly and indirectly, a large proportion of American industries are dependent upon a constant and varied supply of dyestuffs.

\section{DYESTUFFS USED IN THE UNITED STATES.}

The dyestuffs consumed by American industries fall into three classes: Natural organic dyes, mineral dyes, and artificial organic dyes.

Until about 1860 the dyeing trades were restricted to the use of preparations falling in the first two classes. Soon after that date the earlier aniline colors were introduced into general use. The number and variety of these artificial products, made from the different constituents of coal tar, rapidly increased. It was soon possible to replace, in most cases with very pronounced advantages, every tint and shade yielded by natural and mineral dyes, and, in addition, to increase greatly the hues available for color designs in a multitude of industries. The use of the older dyeing materials, both organic and mineral, quickly lessened. To-day, and for some years past, the great bulk of the dyestuffs consumed in the United States consists of synthetic products of the coal-tar chenical industry. The dyestuffs of an earlier day have been in most cases almost completely superseded. In a few instances they play a minor and humble rôle, chiefly as accessories in the use of the artificial dyes.

\section{NATURAL ORGANIC DYES.}

The natural organic dyes are conveniently classified in four subdivisions: (1) Indigo; (2) logwood; (3) red dyes; (4) yellow dyes.

(1) Indigo.-This substance, obtained from various plants of the genus Indigofera, was for centuries the most important of all dyestuffs. Until quite recently it was supplied from Asiatic countries, chiefly from India, and to some extent from tropical America. The natural dyestuff is now replaced almost entirely by the synthetic product, which has manifest advantages in uniformity of strength and shade, as well as in price. The amount of natural indigo now used in the United States is about 7 per cent of the total amount of indigo. 
(2) Logwood.-This dye is extracted from campeachy wood, found in tropical and subtropical America. Our supply comes almost entirely from Jamaica. The extraction of the coloring matter from the wood is done usually in American mills, although a certain amount of extract is also imported. Next to indigo, logwood was, until the past half century, the most important dyestuff known. It was universally employed for the dyeing of black on all classes of fabrics, as was indigo for the production of blue. It is to-day the only natural coloring matter, except indigo, employed extensively by the dyer. While of limited application now on cotton and wool, for the production of very cheap blacks, there is still a large amount used in dyeing silk, to the fiber of which it gives greater opacity than can be obtained from coal-tar dyes. There is also an extended use in dyeing leather. Considerable amounts are employed in connection with dyestuffs, in order to tone slightly the shade produced.

(3) Red dyes.- These include among the dyewoods, Brazil wood, peach wood, Japan wood, and Lima wood, which yield soluble tinctorial matters; and barwood, camwood, and Saunders wood, which contain insoluble coloring substances. None of these to-day has more than a very limited use. Most of the woods in question are supplied by Central America and South America.

Madder, obtained from the root of the Rubia tinctoria, used for centuries to produce the famous "Turkey red," has now almost disappeared from commerce. Its coloring principle, alizarin, has been manufactured synthetically from the anthracene of coal tar since 1871. A small amount of the root is still imported.

Cochineal, a brilliant scarlet, extracted from the female of the insect Coccus cacti, found abundantly on the cactus plant in Mexico and Central America, was once a valued dye for woolens, and is still employed to dye the uniforms of the British army. It resisted longer than madder the invasion of artificial dyestuffs, but its use in the United States is now very limited.

Orchil and its dried extract, cudbear, found very extensive use in producing purplish-red and reddish-brown shades on wool and on silk. It is extracted from lichens, found in abundance on the seacoasts of subtropical countries. Lower California formerly yielded great quantities. At present the use is restricted and limited chiefly to toning the effects produced by other dyes.

Annatto, from the fruit of the Bixa orellana, in South America, has a limited application in silk dyeing. It is more largely used to color cheese.

Safflower, the dried florets of Carthamus tinctorius, has a very slight use for imparting pinks to cheap cottons.

(4) Yellow dyes.-The principal yellow dye is fustic, obtained from the wood of Morus tinctoria, a tree occurring abundantly in the West Indies and Central and South America. Formerly used largely for yellows and olives, it now finds a limited employment for toning logwood effects, especially on woolens.

Quercitron, extracted from a species of oak in the Middle and Southern States, still has a limited use in calico printing.

Persian berries, the unripe berries of the buckthorn, imported from the Orient, are also used to a slight extent for calico printing.

Turmeric, extracted from Curcuma tinctoria, an Asiatic root, has a very restricted use, chiefly in producing composite shades. 
Cutch, obtained from an Indian variety of acacia, is employed slightly for a few brown shades, but more extensively as a tannin mordant on cottons.

The displacement of these natural dyes by artificial colors was not due entirely to the fact that the latter could often be manufactured more cheaply. Most of the vegetable dyes were far removed from being pure dyestuffs. The extracts obtained from woods and plants contained, in addition, a variety of non-tinctorial substances, resins, tannins, sugars, pectinous bodies, etc. It was practically impossible to isolate the pure coloring matter. As a consequence, the extracts varied seriously in their strength, and the colors imparted were dull. The processes of dyeing became easier, simpler, and cheaper, and could be readily standardized. It was further possible to extend greatly the range of colors. Many tones and shades, hitherto unknown, were at the service of the dyer. Most important of all was the fact that the artificial dyestuffs, as a rule, were fast as compared with most of the natural colors. Indigo was the fastest color, and still represents the standard for comparison. Madder was practically as fast, but neither could be obtained from their vegetable sources in a form at all pure or approaching uniformity. The synthetic products were pure and of uniform strength. Cochineal was a fairly fast color, faster than the earlier coal-tar scarlets; and although the latter were cheaper, the animal dyestuff held its own until the appearance of anthracene and chrome scarlets, which possessed even higher degrees of permanence.

The other natural dyestuffs enumerated above were highly fugitive, as compared with the corresponding coal-tar colors, which appeared in rapid succession from 1860 on. Logwood was fast to washing, but not very resistant to light or on exposure to weather. It held its own, howerer, until the appearance of the fast alizarin blacks. Even now it is employed largely for cheap grades of cotton and woolen, and is the one natural dyestuff that continues to maintain a relatively important position in the dyeing branch.

With regard to the sources of the natural organic dyestuffs, it will be noticed that the present supply of the United States is chiefly drawn from the tropical and subtropical regions of the Western Hemisphere. A few materials-natural indigo, cutch, Persian berries, madder, and turmeric - come from Asia. A single dyestuff, quercitron, is indigenous to the United States.

\section{IMPORTATION OF NATURAI, ORGANIC DYES.}

The following table gives the quantity and value of the imports of natural organic dyestuffs into the United States for the fiscal year ending June 30, 1913:

\begin{tabular}{|c|c|c|c|c|c|}
\hline Articles. & Quantity. & Value. & Articles. & Quantity. & Value. \\
\hline 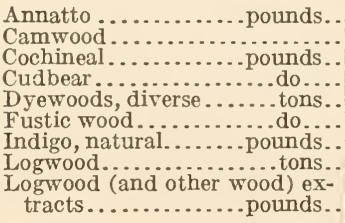 & $\begin{array}{r}405,024 \\
109,089 \\
27,971 \\
155 \\
3,785 \\
231,834 \\
36,952 \\
2,258,206\end{array}$ & $\begin{array}{r}\$ 19,991 \\
191 \\
44,249 \\
1,755 \\
1,794 \\
53,303 \\
88,716 \\
475,484 \\
111,575\end{array}$ & 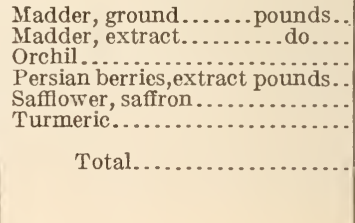 & 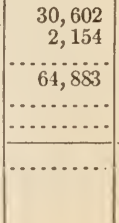 & $\begin{array}{r}\$ 2,803 \\
233 \\
27,386 \\
7,173 \\
93,146 \\
33,735 \\
\end{array}$ \\
\hline
\end{tabular}


The use of inorganic coloring materials for the production of dyeing effects by direct precipitation in the fibers of textiles was formerly of (onsiderable importance. Most of the processes once in vorue are now completely obsolete. 'The few still in occasional use are of minor value and limited application. 'They are comprised in the following list:

Chrome yellow and orange.-These are dependent upon the use of lead acetate and potassium bichromate.

Iron buff.- Obtained by the precipitation of ferric hydroxide from soluble iron salts.

Iron gray.-Obtained by the precipitation of tannate of iron from soluble salts.

Manganese brown.-Precipitation of manganic oxide from soluble manganese salts.

Chrome green.--Obtained by the use of chrome alum. In combination with iron buff this is now employed to some extent to produce the popular khaki effects.

Prussian blue.-Obtained by the use of potassium ferrocyanide and soluble iron salts. There is a somewhat extended use, in connection with other coloring materials, for the dyeing of silk.

Most of the mineral dyestuffs enumerated above are currently manufactured in the United States. Manganese compounds are, however, usually imported from Europe, and potassium ferrocyanide is chiefly of foreign origin. In 1913 the import of this salt from Europe reached a value of $\$ 309,000$.

\section{ARTIFICIAL ORGANIC DYES.}

The great volume of the dyestuffs consumed by American industries to-day consists of organic compounds, usually of very complex composition, the raw materials for which are found in the products of the destructive distillation of coal, as carried on in the retorts of gas works or ovens for manufacturing coke. As already mentioned, the first of these artificial dyestuffs appeared a little over half a century ago, and rapidly, one after another, the natural organic dyes and the mineral dyes were displaced from their positions and reduced to minor and subordinate rank, if not forced to disappear completely from use.

The consumption of the artificial coal-tar colors in the United States has now assumed large dimensions. The increase in this consumption keeps even pace with the growth of American manufacturing industries, and more especially with the development of the various textile branches.

It has been of far-reaching influence in determining the expansion of cotton manufacture. While wool and silk were dyed with comparative facility by vegetable dyes, the contrary was the case with cotton wares. The inert character of the cotton fiber toward tinctorial substances, and the difficulty of mordanting it with metallic salts, caused a serious limitation in the range of colors and processes available for dyeing cotton materials, and greatly restricted their use. The discovery of aniline dyes, capable of dyeing cotton directly, was a notable step forward, despite the fact that these earlier prod$86201^{\circ}-15-2$ 
ucts were not very fast, and could not be employed on fabrics requiring much laundering. The later discovery of the fast vat dyes of the indigo class removed this restriction on the use of colored cotton goods. To-day cotton can be dyed in every variety of tint, and the colors are practically fast, as permanent as the fiber itself. This has led to an enormous development in cotton manufacture, and the products are employed more and more extensively in household economy and for wearing apparel.

The great bulk of the artificial dyes is, however, used on woolen fabrics. These can not be washed frequently without suffering from shrinkage and in other ways. Hence, if intended for articles of apparel and the like, they are almost always dyed, and usually in rather dark colors. This means large quantities of dyestuff. The same rule applies to the vast amounts of woolen material absorbed by the carpet, rug, and upholstery industries. Such wares require a great consumption of acid dyes, indigo, and the alizarin colors, with smaller amounts of the other fast vat dyes. Most of the latter, involving application in strongly alkaline solutions, are in consequence not adapted for use on wool fibers.

The great diversity of the modern demands for colored textiles, paper, and the like, has called for equal diversity in the dyestuffs employed, not only as regards color, but also as regards fastness to light or washing.

At present the American demand calls for over 900 different artificial dyestuffs. A small group includes color's used in very large amounts. In another much more numerous group fall colors employed in moderate but still noteworthy quantities. The majority of the dyes enumerated in current price lists are demanded in small amounts and for special purposes or qualities. This third category includes most of the very high-priced dyestuffs. The necessity of providing the great varicty of colors found in this category is a dominant factor in the dyestuff industry.

\section{DOMESTIC MANUFACTURE OF ARTIFICIAL DYESTUFFS.}

The demand for artificial dyes in the United States is met to some extent by the domestic coal-tar dye industry. The great bulk of dyes used, however, is imported from Europe, Germany being the chief source.

It is not easy to estimate the value of the current annual production in the United States of coal-tar dyestuffs. Estimates furnished by those engaged in the manufacture range from $\$ 2,000,000$ to $\$ 5,000,000$. The census report of 1909 gives $\$ 3,462,000$ as the value of artificial dyestuffs produced in that year. Among our exports of domestic manufacture there has been for five years an average export of "dyes and dyestuffs" amounting to $\$ 345,000$. It is doubtful whether artificial dyestuffs constitute any appreciable share of this item, a large portion of which goes to Canada. It is probable that the American consumption of artificial dyes of domestic origin does not vary much from $\$ 3,000,000$ per annum.

The returns of our foreign commerce for the fiscal years ending June 30, 1909-1914, give the following values for the imports into the United States of coal-tar dyestuffs: 


\begin{tabular}{|c|c|c|c|c|c|c|}
\hline Articles. & 1909 & 1910 & 1911 & 1912 & 1913 & 1914 \\
\hline $\begin{array}{l}\text { Mlizarin and alizarin dyes.. } \\
\text { Artiticial indigo............... } \\
\text { Other coal-tar dyes......... }\end{array}$ & $\begin{array}{r}\$ 1,215,700 \\
1,242,149 \\
5,901, \$ 42\end{array}$ & $\begin{array}{r}\$ 647,944 \\
1,045,375 \\
6,011,054\end{array}$ & $\begin{array}{r}\$ 705,346 \\
1,009,709 \\
6,022,9 \times 6\end{array}$ & $\begin{array}{l}\$ 1,3 \$ 1,936 \\
1,017,516 \\
6,965,121\end{array}$ & $\begin{array}{l}\$ 1,817,270 \\
1,014,181 \\
7,105,254\end{array}$ & $\begin{array}{r}\$ \$ 1.5,459 \\
1,015,201 \\
7,241,406\end{array}$ \\
\hline Total.. & $8,359,691$ & $7,704,373$ & $7,741,011$ & $9,364,573$ & $9,936,735$ & $9,102,066$ \\
\hline
\end{tabular}

Alizarin and indigo and their derivatives are imported duty free. Other artificial dyes pay a duty of 30 per cent. The figures for indigo do not include natural indigo from Asia, and from British ports. The annual value of the imports of natural indigo has sunk from $\$ 15 \$, 000$ in 1909 to $\$ 78,000$ in 1914. Coal-tar dyes paid in 1913 duties amounting to $\$ 2,071,000$ and in 1914 to $\$ 2,261,361$. There is a small export, chiefly to Canada, of foreign-made artificial dyes. Its value in 1913 was $\$ 46,249$, and in $1914 \$ 38,257$.

The German official statistics for the calendar year 1913 give the export of dyes to the United States as $\$ 9,030,000$, and the imports of such wares from the United States as $\$ 12,000$.

The average annual value of the imports of coal-tar dyes during the last three years was $\$ 8,781,736$. This is the cost price abroad. With added amounts paid for duties, about $\$ 2,000,000$, and expenses and profits, the sum annually expended for foreign coal-tar dyes exceeds $\$ 12,000,000$. Assuming the ralue of the colors manufactured and employed in the United States to be approximately $\$ 3,000,000$, it is found that American consumers are now paying annually about $\$ 15,000,000$ for coal-tar dyes.

\section{FOREIGN SOURCES OF ARTIFICIAL DYESTUFFS.}

If the general imports of coal-tar dyes into the United States are analyzed as to country of origin, the following is found to be the case for the imports of 1913: Of alizarin and derivatives, Germany supplies 99 per cent; of synthetic indigo, Germany supplies 96 per cent, and Switzerland, 2.4 per cent; of other coal-tar dyes, Germany supplies 81 per cent, Switzerland 12 per cent, the United Kingdom 2.8 per cent, Belgium 2.5 per cent, and France 1.0 per cent.

The import from Belgium is supposed to be largely of German origin. The total value of the German import in 1913 was $\$ 8,538,000$. It constituted 86 per cent of the value of imported artificial dyestuffs.

The Swiss import reached $\$ 918,232$. It formed 9 per cent of the total value. It will be seen that, apart from the modest contribution of Switzerland, the United States depends almost entirely on Germany for its supply of imported artificial dyestuffs.

ECONOMIC EFFECTS OF DEPENDENCE UPON A SINGLE FOREIGN SOURCE.

The economic dependence of the United States, and in fact of all nations, upon a single foreign source for the regular supply of an important class of manufactures is comparable in many respects to the general dependence upon Chile for saltpeter, upon Russia for platinum, and upon Germany for potash, all three being natural monopolies. 
The danger inherent to such a state of dependence has been sharp.y brought to view in the world-wide experience of the last seven months. Some countries have been deprived almost entirely of their customary supplies of artificial dyes. In others, notably in our own land, the supply has been intermittent and its continuance uncertain.

Thousands of American industrial plants and an army of operatives, with their dependents, have been threatened with a serious arrest of manufacturing activities. In many cases it has been impossible to fill contracts; in a multitude of instances managers of large establishments have had to grapple seriously with the problem of how to continue manufacture with limited supplies or with no supplies of the customary coloring matters.

Fortunately, after the first excitement following the outbreak of hostilities, in August, 1914, and the interruption for some weeks of all shipments of foreign dyestuffs, means were found to resume the exportation from Germany and Switzerland. By the close of 1914 most American manufacturers had been supplied with the majority of their customary supplies of coal-tar dyes in nearly normal amount.

On August 1, 1914, the textile works had supplies adequate for the needs of their mills for two or three months. The German Government granted permission for the monthly export to the United States, in American vessels, of a maximum allowance of 2,300 tons of artificial dyestuffs.

The result has been that, while a few cases of hardship were unavoidable, and here and there changes in style, etc., were required, textile branches have not materially suffered thus far.

\section{INCREASED COST OF COAL-TAR DYES.}

There has been an increase in the cost of dyes, naturally inevitable with the rise in freight rates and insurance. In September, 1914, the average increase on foreign dyes was estimated at about 25 per cent. Since then there has been a rise of about the same amount. The price of alizarin is now about 50 per cent above that of August, 1914. In some instances very abnormal rates are quoted. Benzopurpurin, an important cotton dye, selling ordinarily at 14 cents per pound, is now (Mar. 15) quoted at 80 cents.

American manufacturers of dyes have been able to retain old rates on about one-third of their products, while the prices of the rest have doubled in consequence of the increased cost of raw material. In general, there has been a pleasant concurrence of opinion on the part of American consumers of dyestuffs that the few American manufacturers in this branch have taken no undue advantage of the critical situation, and, further, that the resident agents of foreign makers have shown great resolution and energy in seeking to secure supplies for their regular customers and in distributing equitably such as have been received.

\section{OUTLOOK FOR THE IMMEDIATE FUTURE.}

While nearly enough coal-tar dyes are now being shipped from Germany to meet the current needs of American consumers, the fact is not disguised on either side of the ocean that at any moment this supply may be largely or totally suspended. Several factors enter here into consideration. Naval operations in the existing war 
may assume such a character that maritime connections with the port of Rotterdam may be completely severed. There is in this case a possibility of utilizing an Italian port, such as Genoa, from which small amounts of dyes have already been shipped to New York.

The German supply of benzol may be commandeered for use in motors in place of gasoline. Benzol is the raw material absolutely essential for the manufacture of the majority of aniline dyes.

'The German Gorernment may require for military purposes, in the manufacture of explosives, the entire available stock of nitric acid. 'This would be practically equivalent to closing nearly every factory engaged in making dyestuffs. There is hardly a dye made, except alizarin, in the manufacture of which nitric acid is not required.

Some classes of dyestuffs may be crippled in their manufacture by the lack of an important raw material. Carbolic acid is used in large amounts for the manufacture of explosives. It is also indispensable for the production of a variety of dyes.

It is thus evident that any prolongation of the existing war increases the probabilities of a serious famine in artificial dyestuffs.

\section{ALTERNATIVES IN CASE OF A DYESTUFF FAMINE.}

Responsible heads of textile works who have studied the problem find three outlets from the dilemma:

(1) The textile industries may be forced to put upon the market, to a large extent, goods that are undyed. This would be an unsatisfactory solution. The demand for such goods would certainly fall below the normal, and there would be a serious drop in prices.

(2) A return may be made temporarily to the use of natural dyestuffs. In some instances vegetable substitutes can be obtained with tolerable rapidity. This would be particularly the case with logwood. The output can be quickly increased and provision made for dyeing black on both cottons and woolens, although at the sacrifice of fastness. Fairly ample supplies of orchil can be secured at short notice and can be used for reds and browns in dyeing carpets and woolens generally. There would also be no great delay in obtaining a stock of yellow woods. Considerable time would be lost, however, before the coloring matters could be extracted and properly treated in order to develop desired strength and quality. In the case of indigo and madder several years would elapse before the needed stocks could be obtained. It would be scarcely possible to collect more than a fraction of the cochineal required for scarlets. The majority of tints now in common use could not be produced at all. Needless to say, there would be involved a revolution in the methods of dyeing.

(3) The attempt could be made to build up rapidly an American coal-tar dyestuff industry, self-contained and independent, based upon the use of American raw materials, and providing American consumers with all needed artificial dyestuffs. This would certainly demand some time, but would insure permanent freedom in the future from the dangers to which so many of our great industries are now exposed.

The desirability, and even urgency, of adopting the necessary measures for the creation of such a national industry have been advocated most earnestly by consumers of dyestuffs, by chemists, and by economists. 
It seems proper here to consider why such a complete industry has not yet been established in the United States, and under what conditions it can be called into existence. This inrolves a study of the existing coal-tar chemical industry in the United States, its limitations, and its successes, and a study of the German coal-tar industry, with the explanation of its present technical and commercial domination in the world's trade.

\section{OUTLINE OF THE COAL-TAR CHEMICAL INDUSTRY.}

When coal undergoes destructive distillation in coke ovens or gas retorts, the average products are as follows: Coke, 72 per cent; gas, 22 per cent; tar, 6 per cent.

The tar contains some 155 different chemical compounds, none of which are dyes. Ten of these substances are utilized in the manufacture of dyestuffs. They are: Benzol, toluol, xylol, phenol, cresol, naphthalene, anthracene, methyl anthracene, phenanthrene, and carbazol. The first three are present to a considerable extent in the crude gas, given off on distillation. Only by the use of specially designed purifiers can they be remored or separated.

The 10 substances enumerated form 6 to 12 per cent of the coal tar, the amounts varying according to the character of distillation. The arerage yield is about as follows:

\begin{tabular}{|c|c|c|}
\hline Substances. & $\begin{array}{l}\text { Percent- } \\
\text { age of } \\
\text { tar. }\end{array}$ & $\begin{array}{l}\text { Percent- } \\
\text { age of } \\
\text { coal. }\end{array}$ \\
\hline 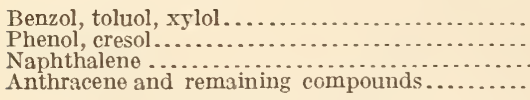 & $\begin{array}{r}1.75 \\
.25 \\
5.95 \\
.20\end{array}$ & $\begin{array}{r}0.115 \\
.015 \\
.357 \\
.012\end{array}$ \\
\hline
\end{tabular}

These 10 primary, or crude, coal-tar products are separated from one another, and from the great varicty of carbon compounds accompanying them in the tar, by fractional distillation. This operation is carried on in the tar distilleries, which supply likewise pitch, creosote oil, naphtha, and other crude mixtures of coal-tar constituents.

From the 10 primary "crudes," chemical works of a high character prepare nearly 300 so-called "intermediates," compounds that are not dyes, but which are susceptible by direct reactions of being transformed into coloring matters. A number of these intermediates serve also in the manufacture of medicinal preparations, photographic chemicals, etc. Leading intermediates are aniline oil and salts, pure aniline and toluidine, nitrobenzol, naphthol, phthalic acid, salicylic acid, resorcin, anthraquinone, etc. These intermediate products serve as the raw material for the manufacturer of dyes. From them he makes over 900 different-dyestuffs now currently sold in the world's markets.

In a general way it may be stated that the arerage intermediate sells for five times as much as the average crude coal-tar derivative, and the average finished dye for ten times as much, a very material enhancement in value.

The number of intermediates now in active use does not exhaust the possibilities in this class. Many hundred more are known to the chemist and can be employed in dye manufacture. Less than 300 
have been found sufficient to meet the neods of makers and to eombine technical with economic advantages.

'The same may be said of finished dyes. 'The number of possible distinct dyestufts corered by patent specifications up to the present would run into the millions. Of the many possibilities only 900 have won a recognized position, and of these only 400 are of very extended use.

It is doubtful whether many additions of value will be made to the current list of artificial dyestufis in the immediate future. 'The field has been worked most thoroughly by color chemists. During the past decade only a single new class of dyes has been discovered and placed on the market.

Briefly summarizing the coal-tar dyestuff industry, the following features are obviously essential to success:

The presence of an ample supply of coal.

The extensive use of this coal for gas and coke manufacture.

The use of a plant that allows the recovery of the volatile organic compounds formed during destructive distillation.

The industrial treatment of the tar produced, so as to separate and furnish in a fairly pure form 10 crude substances.

The existence of well-equipped chemical works, able to transform the 10 crudes into nearly 300 more complex intermediate compounds.

The existence of highly organized works for manufacturing from these intermediates some 900 different dyestuffs.

An ample and sure supply of a variety of acids and heavy chemicals for effecting the numerous transformations.

A relatively large number of chemists who have enjoyed university training.

\section{COAL-TAR DYE INDUSTRY IN THE UNITED STATES.}

Considering the natural resources and economic conditions of the United States, it could reasonably be expected that a well-developed coal-tar chemical industry would flourish here.

The coal supply is abundant. The unmined coal deposits are five times greater than the reserves of Europe. Large amounts of coal are used in furnishing an illuminant and fuel for a population of $100,000,000$. Still larger amounts are consumed in providing coke for the enormous iron and steel industry.

The consumption of artificial dyestuffs is large-about $\$ 15,000,000$ in value annually, as already noted.

The many universities and schools of science are furnishing yearly a considerable number of well-equipped young chemists.

Nearly all of the world's great industries are encountered in the United States, finely developed, with high standards of efficiency.

And yet, despite these favoring conditions, the production of artificial dyestuffs in the United States is hardly half of that manufactured in Switzerland, a small country without a coal mine.

\section{SLOW DEVELOPMENT OF THE AMERICAN INDUSTRY.}

The first aniline dye, mauve, was discovered by Perkins, in England, in 1856. It was followed in the same year by magenta and fuchsine, and the manufacture began in England on a small and not very remunerative scale. Little progress was made until the appearance, in 1862 , of the soluble blues. Then followed in 1863, Hoffman's violet and Bismarck brown; in 1864, naphthol yellow; in 1867, the nigrosines. 
The manufacture was taken up with great energy in both Germany and Switzerland. A vast amount of patient, intelligent, and careful research was expended upon the new field. The industry was started in France and England, but with less zeal and scientific research.

In 1871 artificial alizarin appeared, and a few years later saw the discovery of chrysoidine, malachite green, eosine, and a number of the current standard dyes. The manufacture was growing rapidly in Germany and becoming well intrenched.

During this period the consumption of aniline dyes assumed large proportions in the United State, which became the leading customer of the German factories.

There seemed a good opening for American enterprise, and in 1879 the first establishment for the manufacture of artificial dyestuffs was started at Buffalo. Eight others were opened soon after. At that time the manufacture was based upon the use of the intermediates imported from Europe. It was difficult to obtain an adequate supply of benzol from domestic tar works. The Buffalo works did, for a few years beginning with 1884, make its own aniline oil, but was forced to abandon the attempt on account of the uncertainty of obtaining the raw material.

The industry was exceedingly remunerative at the outset. There seemed to be a good prospect of soon becoming independent of other nations in this branch, except so far as patent protection existed, although for the time being the industry was based upon the use of intermediates of foreign origin, procured from Germany and Great Britain.

In 1883, however, the growth of the industry was suddenly checked. Within a year five of the nine establishments were forced to close. The other four continued to manufacture on a close margin. These four having been carefully conducted, have gradually developed and now seem to be flourishing. The capital invested is estimated at $\$ 2,000,000$ to $\$ 3,000,000$ and the annual output is about $\$ 3,000,000$. There is not much competition between the different firms, each specializing to some extent, one for woolen dyes, another for cotton, another for paper, etc. All have to meet keen competition on the part of the representatives of German manufacturing firms, and the claim is made that they have to contend with underselling. Three of these establishments are in the vicinity of New York. The oldest and largest is still located in Buffalo. It has shown a commendable degree of enterprise, having taken out 16 patents for new colors and intermediate products. Two of its patented products are manufactured extensively in Germany under license.

These firms have employed intermediates, mostly from Germany, as the basis of their manufacture. The works at Buffalo have, however, as already mentioned, made aniline oil on a large scale, and have also demonstrated their ability to manufacture in technically pure form quite a group of intermediates, such as nitrobenzol, dinitrobenzol, nitrotoluol, dinitrotoluol, dimethylaniline, and a variety of sulphoacids. Pure phenol and pure naphthalene have also been made in their works. In all cases the production has been abandoned because German makers reduced their prices on intermediates to such an extent that competition became hopeless.

During the last seven months, when it has been almost impossible to obtain intermediates from Europe, the American works have hur- 
riedly put up emergency plants and made the requisite intermediates at considerable expense in order to avoid a complete stoppage. In this comnection material assistance has been rendered by the introduction in 1911 of the manufacture of nitrobenzol and aniline oil and salts in the works of one of the largest American companies engaged in the production of chemicals. This company has been able to supply about one-quarter of the demand of American dyestuff manufacturers for the intermediates in question.

The quality of these compounds has been recognized as fully equal to that of European products, and the ability to make these compounds in the United States from American benzol, so hotly contested on the other side of the ocean, has been abundantly demonstrated.

A plant is now under erection that will be able to provide for onehalf of the needs of the American color makers, as far as aniline oil and salts are concerned, and will be capable of easy expansion.

The dyes manufactured by the four American establishments are chiefly standard colors, called for in fairly large quantities, on which patent rights have expired. They number about 100 and represent the active types in the trade. No attempt is made to manufacture synthetic indigo, which remains under patent protection for a few years longer, or alizarin, which requires an exceedingly expensive plant. Both of these dyestuffs are on the free list.

Mention should be made of a fifth factory for making coal-tar dyes which has been established in the State of New York by one of the largest German firms engaged in the manufacture. This branch house, according to statements, is occupied with the transformation of intermediates into finished dyes, especially in such cases where the series of operations is costly, and the last steps relatively simple and inexpensive. There is manifestly a temptation to utilize tariff provisions in this manner, and the practice is probably not limited to the one foreign branch. An unfinished dyestuff pays 10 per cent duty or no duty, as compared with a duty of 30 per cent on the finished product. The cost of the last steps in "assembling" the finished dye, may, however, be less than 1 per cent of its total value.

Reviewing the growth and present status of the manufacture of artificial dyestuffs in the United States, it may be said that all has practically been accomplished that could safely be attempted in the face of exceptionally powerful competition. Those conducting these industries have shown an abundant measure of perseverance and patience in facing economic difficulties and gradually building up as extensive a structure as now exists. There seems to be present a determination and readiness to invest capital and energy on a large scale in expanding the industry as soon as the factors of safety are assured.

\section{AMERICAN SUPPLY OF RAW MATERIALS.}

As already noted, attempts in the past to manufacture intermediates have been hampered by the insufficiency of the domestic supply of coal-tar crudes. It is desirable at this point to know exactly how far the recovery of the by-products of American gas works and coke ovens is developed and to what extent they can supply in the immediate future the crudes needed by an expanded coal-tar chemical industry. The two sources of coal tar are gas works and coke plants. 


\section{COAL TAR FROM GAS WORKS.}

In 1909, according to the census returns, the coal used in American gas works amounted to 4,941,000 tons, valued at $\$ 16,305,000$. At the same time $580,000,000$ gallons of oil, valued at $\$ 17,346,000$, were employed in the production of gas. The tar collected was 92,153,000 gallons. Of this quantity $78,340,000$ gallons, valued at $\$ 1,876,000$, appear to have come into the market. The valuation is a little over 2 cents per gallon. This tar is not rich in the hydrocarbons benzol, toluol, and xylol, as it is sought to retain as large a volume as possible of these volatile constituents in the gas, in order to increase the illuminating power. Coal gas usually contains from 0.5 to 1.2 per cent of benzol and its homologues. On an arerage, when coal is distilled, 100 pounds of coal yield 1.25 pounds of benzol and its higher homologues that are present in the gas erolred. Of this amount 0.94 pound is pure benzol, and 0.31 pound is toluol and xylol. A small additional amount is found in the tar. It consists of 0.05 pound of benzol, and 0.08 pound of toluol and xylol.

The coal tar from gas works contains on an arerage 0.32 per cent of pure benzol, 0.50 per cent of toluol and xyol, 0.26 per cent of pure phenol, 4.5 per cent of pure naphthalene, and 0.44 per cent of pure anthracene.

Assuming that the present American production of gas tar amounts to $100,000,000$ gallons, this represents about $1,000,000,000$ pounds, or 500,000 short tons. From this quantity it is possible, on the above figures, to extract: Benzol, 1,600 tons; toluol and xylol, 2,500 tons; phenol, 1,300 tons; maphthalene, 22,500 tons; anthracene, 2,200 tons; and the minor constituents, cresol, phenanthrene, etc., in proportion.

\section{COAL TAR AND BENZOL, FROM COKE WORKS.}

The majority of the coke plants in the United States are equipped with old-fashioned beehive orens, which allow all gas, ammonia, and tar to be wasted.

Modern recovery orens, with condensation plants, hare been installed to some cxtent in this country. Their use is much more extended in European coke works, especially in Germany, where nearly all the by-products are saved. In 1913 there were 102,650 coke orens in the United States, and of these only 5,688 were retort, or recovery, ovens. The increase during the year of such ovens was 477. There was a decrease in the number of beehive orens of 57 . At the close of the year 504 retort orens were under construetion, and contracts had been made for building many more. During 1913, 30,485 bechive orens-31.4 per cent of the entire number-were idle throughout the entire year.

In 1912 the amount of coal used for coke plants reached 65,578000 , short tons. The coke produced totaled $32,869,000$ tons, ralued at $\$ 69,172,000$, from beehive ovens, and $11,115,000$ tons, ralued at $\$ 42,633,000$, from recovery orens; in all, $43,984,000$ tons, valued at $\$ 111,805,000$. The coke obtained from the recovery ovens represents 25 per cent of the total product in quantity and 38 per cent in value.

The retort ovens are expensive, but the increased outlay is more than compensated by the ralue of the ammonia, tar, and gas recov- 
ered, especially if there is an adequate demand at hand for the gas. The recovery plants contain the necessary condenser's for collecting ammonia and tar, but are not always provided with the "scrubbers," or benzol towers, designed to extract from the otherwise purified gas the benzol and toluol present therein and cnhancing the value for illuminating purposes.

In the towers the current of gas comes in contact with the heavier oils obtained in the distillation of coal tar, and the benzol and toluol present are largely absorbed by them. The oils, when saturated, are run into a still, and the benzol and toluol are driven out by heat and are collected in suitable condensers. Benzol towers constitute an important additional item of expense, and introduce an additional complication into the general process. They give a yicld of about 22 pounds of benzol and toluol for each ton of coal submitted to coking. Their construction has hitherto been largely dependent upon the current demand for these hydrocarbons. The cost of benzol towers for a plant coking 300 tons of coal daily is about $\$ 21,000$ in Germany. It requires a capital of about $\$ 5,000$ for operation. 'The operating expenses are about $\$ 23,000$ per annum. Such a plant gives yearly profits exceeding $\$ 30,000$ when benzol prices are favorable. With low prices for benzol it may barely meet the cost of operation. The 65,000,000 tons of coal now employed in coking are capable of producing 715,000 tons of benzol and its homologues from benzol towers alone, but the cost of the necessary plant would be over $\$ 14,000,000$.

It is estimated that our present system of coking involves an annual loss of $\$ 75,000,000$, but at the present rate of advance, by 1920 onehalf of our coke supply will come from recovery ovens. The introduction of such ovens in the United States began in 1892.

The tar recovered in Amcrican coke plants was 66,300,000 gallons in 1910. It rose to $94,300,000$ gallons in 1912, with a value of $\$ 2,311,000$, or 2.45 cents per gallon. The weight of this tar was about 944,000 tons. Taking as a basis the customary yield obtained from coke tar, this contains 16,420 tons of benzol, toluol, etc.; 2,380 tons of phenol; 56,600 tons of naphthalene; and 1,890 tons of anthracene, and the minor constituents in proportion.

From the 65,000,000 tons of coal now used in coking it would, however, be possible, with complete recovery plants, to obtain $3,350,000$ tons of tar, or three and one-half times the present quantity. This would mean a potential supply from the tar of coke plants, on an existing basis of production, of approximately 58,000 tons of benzol, toluol, etc.; 8,300 tons of phenol; 200,000 tons of naphthalene; and 6,700 tons of anthracene.

Together, the existing gas and coke production, provided the latter be completely equipped with recovery plants, can furnish tar and benzol capable of yielding annually approximately 780,000 tons of benzol; 9,600 tons of phenol; 222,000 tons of naphthalene; and 9,000 tons of anthracene; and the minor compounds, cresol, methyl, anthracene, phenanthrene, and carbazol in the customary relative proportions.

From existing American gas works and coke plants, as equipped at present, about 25,000 tons annually of benzol, toluol, and xylol can be obtained if there is sufficient demand, and the proportionate quantities of the other constituents. 
These figures for the possible and potential production in the United States of the crude coal-tar products may be compared with those for the production in Germany.

In 1910 Germany was equipped to produce, if necessary, 98,000 metric tons of benzol and its homologues (metric ton $=2,204.6$ pounds). The actual production was 66,000 tons. Of this, 56,000 tons were benzol and 10,000 tons toluol and higher homologues. A little over one-half of the total product was sold for use in motors, automobiles, etc. Aniline color works required 32,300 tons. As Germany supplies over two-thirds of the finished coal-tar dyes now produced, and the great bulk of the intermediates required in other countries, furnishing from German works nearly all of the crudes, it is evident that the United States has at hand the raw material requisite for supplying the crudes needed in the manufacture of over onehalf the world's supply of artificial dyestuffs. At the same time its coke industry is capable, upon demand, of furnishing in the future twenty times as much benzol, etc., as the world now requires for coal-tar colors.

\section{PRESENT PRODUCTION OF CRUDE TAR PRODUCTS.}

The handling of coal tar and its further treatment are concentrated in a few hands, as is the case in Germany. This has given to the industry a pronounced unity and economy. Consumers of coal-tar crudes state that there has been a marked disposition to meet their needs, and to so adapt and modify manufacturing processes that domestic demands may be met as far as general market conditions permit.

In 1911 the amount of coal tar subjected to distillation amounted to $56,000,000$ gallons. The remainder of the tar production was employed in the manufacture of roofing paper and for sprinkling streets. There is not much attempt to obtain separate products in a state of purity. The most important products are the light oil, creosote oil, and the residual pitch. These articles can compete successfully with European products. The light oil, containing benzol, etc., constitutes about 1 per cent of the tar. It is used largely for a solvent, for cleaning purposes, and as an illuminant. The creosote oil constitutes about 23 per cent of the tar and is used extensively for preserving timber. The domestic supply is far from covering the current demand.

In 1914 the United States imported $61,000,000$ gallons of creosote oil, valued at $\$ 3,840,000$, Great Britain supplied $41,000,000$ gallons, Germany $10,000,000$, and the remainder came largely from Belgium and the Netherlands. The home production of creosote oil in 1909 was $13,000,000$ gallons. It has about doubled since then.

With regard to the production in the United States of the coal-tar crudes, necessary for dyestuff manufacture, the following is the situation:

Benzol, toluol, xylol.-Such limited amounts as have been called for to make intermediates in American works, about 500 tons annually, have been supplied the last few years. Provision can be quickly made for an ample supply on a much more extensive scale if a permanent demand is evident. 
Phenol, or carbolic acid.-The method of treating American coals is such as to favor a relatively low production of phenol in coal tar. 'There has been little attempt to separate, regularly, technically pure phenol from the tar distillates.

The American demand is covered mostly by importations from abroad. In 1913 American imports were valued at $\$ 675,000$. Of the import of 4,077 tons, Germany supplied 1,354 tons, Great Britain 2,422 tons, and the Netherlands 287 tons. The average price was $\$ 166$ per short ton. In addition to furnishing material for a variety of important dyes, phenol has an extended use in medicine, in the manufacture of explosives, and in various industries. One important chemical made from phenol is salicylic acid, widely used in medicine as well as in the manufacture of artificial dyes. This is imported to the extent of 32,000 pounds. Another derivative is picric acid, used as an explosive as well as a dye. The import is now 85,000 pounds, valued at $\$ 18,000$.

The embargo on exports of phenol from Europe during the last few months, on account of its importance in connection with military supplies, has forced American chemists to fall back on its synthetic production from benzol. The operation is relatively easy. It is based upon the transformation of benzol into its sulphonic acid by the action of sulphuric acid, and the fusion of the product with caustic soda. With an ample supply of benzol the manufacture of synthetic phenol in the United States could be readily assured, at a cost not much in advance of that of the European product.

Naphthalene.-This is a leading constituent of coal tar and furnishes a variety of derivatives employed in dye manufacture. The bulk of the pure product is used as a moth preventive. The United States consumes annually about 5,000 short tons. Nearly 1,600 tons are supplied by American tar distillers. The remainder comes from Germany and Great Britain, in about equal amounts. Phthalic acid, one of the most important derivitives of naphthalene, is imported to the extent of 38 tons annually, with a value of $\$ 21,000$. Naphthalene is a prominent constituent of the fraction of creosote oil obtained in the distillation of coal tar. It is a purely commercial question to the tar distiller, whether he can more profitably sell the crude creosote oil or separate out the naphthalene present therein.

Anthracene.-This hydrocarbon is also present in the creosote oil, and the same question arises as to the profit of its separation. No attempt is made in American tar works to isolate this valuable constituent, which serves as the basis of the manufacture of synthetic alizarin and all the alizarin dyestuffs.

The same may be said of the relatively small but still important amounts of cresol, methylanthracene, phenanthrene, and carbazol, all of which occur in the creosote oil, and all of which are essential to an industry providing all current artificial dyestuffs. It should be mentioned here that the quantity of anthracene present in the coal tar now treated in American tar works is far in excess of that required to manufacture the alizarin dyes imported into the United States, while the naphthalene present could more than meet the demands of the world's entire dyestuff manufacture.

A competent authority gives the following estimate for products of the coal-tar industry in the United States for 1914: Total pro- 
duction of refined benzol in all forms, 2,550,000 gallons, or about 9,600 short tons (of this amount, 200,000 gallons, or 750 tons, was deroted to the manufacture of aniline compounds); total production of refined toluol, in all forms, 840,000 gallons, or about 3,200 tons (nearly all used for making explosires); production of refined phenol, 75 tons; production of refined naphthalene, 1,500 tons.

\section{PRICE MOVEMENT OF AMERICAN COAL-TAR CRUDES.}

Since August 1, 1914, there has been a steady movement upward in the market rates for nearly all crude products of coal tar, required in making dyestuffs or explosives. The following table shows the increases:

\begin{tabular}{|c|c|c|}
\hline Crudes. & $\begin{array}{c}\text { Aug. 1, } \\
1914 .\end{array}$ & $\begin{array}{c}\text { Feb.15, } \\
1915 .\end{array}$ \\
\hline 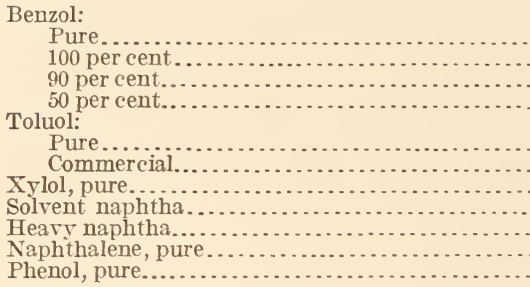 & $\begin{array}{c}\$ 0.30 \\
.27 \\
.25 \\
.26 \\
.35 \\
.27 \\
1.20 \\
.27 \\
.18 \\
.023 \\
.075\end{array}$ & $\begin{array}{r}\$ 0.40 \\
.37 \\
.35 \\
.38 \\
.45 \\
.40 \\
1.20 \\
.27 \\
.16 \\
.033 \\
1.00\end{array}$ \\
\hline
\end{tabular}

The present quotation for phenol is nominal. The demand for phenol is so far in excess of the supply, foreign or domestic, that exaggerated prices are often offered without finding any taker. American toluol is used almost entirely for producing high explosives. The naphthas, mixtures of the hydrocarbons, not used for dyestuffs, etc., show no tendency to rise.

\section{POSITION OF TIE AMERICAN TAR DISTILLER.}

The tar industry of the United States is on a different basis from that of Europe. In Europe its importance is confined almost entirely to the production of raw material for a highly organized chemical industry. Here the use of tar itself is widespread, while the utilization of its chief constituent, pitch, is confined to very narrow limits across the ocean. Pitch forms 70 per cent of coal tar. In Germany little use is made of it except as a fucl. Nine-tenths of the pitch supplied by American tar works is employed in road making, in roofing, and in general waterproofing.

The rery extended use of creosote oil in the United States makes it a purely commercial question as to whether the tar distiller should attempt a refining of its constituents. The current demand in America for benzol, toluol, and xylol is entirely met by the product from the benzol towers of coke plants.

To attempt any extended provision for supplying the entire range of coal-tar crudes, such as might be required in the United States for the manufacture of its own supply of artificial dyestuffs, would mean an assurance that the distiller could profitably dispose of nearly all of the products isolated in a more or less pure form during 
the various processes, and secured in far diflerent proportions from those required in the gencral manufacture of coal-tar dyestufis. $\Lambda t$ once he would face a very delicate and complicated problem, with many factors, technical, economic, financial. 1 dominant factor is an assured market, if he cularges his plant on a scale comparable with forcign establishments.

Less than 10 per cent of tar consists of matters available for use in the dyestuff industry. If a distiller attempts to meet the needs of a growing or rapidly expanded domestic dyestuff industry, he must find chamnets for disposing of the remaining 90 per cent.

'The tar distiller feels that he should not be expected to embark in the manufacture of intermediates, but that this branch should be undertaken preferably by the producer of heavy chemicals, as the production of intermediates means a heavy consumption of acids, alkalies, and a variety of other chemicals.

There seems to be no lack of enterprise in the tar-distilling branch; but there does seem to be a deep-seated conviction that fundamental changes in legislation are absolutely essential bcfore any far-1'eaching effort call be organized, to assure the preparation from American coal tar of an adequate supply of "crudes" for the needs of a selfcontained American coal-tar dyestuff industry.

\section{SUPPLY OF GENERAL CHEMICALS REQUIRED.}

With regard to the great bulk of the heavy chemicals required in the coal-tar dyestuff industry, the United States is now comparatirely independent of the rest of the world. This is especially the case with sulphuric acid, hydrochloric acid, sodium carbonate, caustic soda, wood alcohol, grain alcohol, and the chromates, all of which are used in large amounts. Liquid chlorine can easily be produced here on a large scale by electrolytic methods if the demand exists. The same can be said of glacial acetic acid and of acetic anhydride, the raw material for which is furnished abundantly by numerous plants for wood distillation. In common with the rest of the world, the United States depends largely upon Germany for potash compounds. The world depends likewise upon Chile for the raw material required in making nitric acid and sodium nitrite, except as these products are obtained from the air by the new processes for oxidizing atmospheric nitrogen. There is promise of this new industry being created in the United States. For the time being Norway, with its very cheap water power for generating electricity, is the only country where the synthetic production of nitric acid is a pronounced success on a fairly large scale. Most of the nitrite required for the manufacture of coal-tar dyestuffs is very advantageously manufactured as an adjunct of the Norwegian nitric-acid production. The bulk of the nitric acid made in Norway is transformed immediately into nitrates for use as fertilizer. All of Norway's water power, if utilized for the production of nitric acid and nitrates, would suffice for the production of only a fraction of the world's demands. In this connection it is of interest to note that Germany has hastily erected works on the Rhine for the production of nitric acid from atmospheric nitrogen, generating the necessary electric current at high cost by means of coal. The works will be in operation by April, 1915, and will partly meet the rastly increased demand for nitric acid required in the manufacture of explosives. 


\section{THE GERMAN COAL-TAR DYESTUFF INDUSTRY.}

As already noted, all efforts to build up on a large scale a distinctly American coal-tar chemical industry have been crippled and rendered useless when brought into conflict with the interests of the German coal-tar chemical industry. It is necessary to analyze the sources of this power, exerted apparently with such ease in all the leading industrial countries of the world, but felt most keenly in the United States, with its abundant supply of the raw materials and its large and rapidly growing consumption of artificial dyestuffs.

First of all, it is important to establish just how large a proportion of the world's production of artificial dyes is made in Germany. From export returns and careful estimates of local consumption, the following may be regarded as a fairly approximate statement of the world's present production of finished coal-tar dyes:

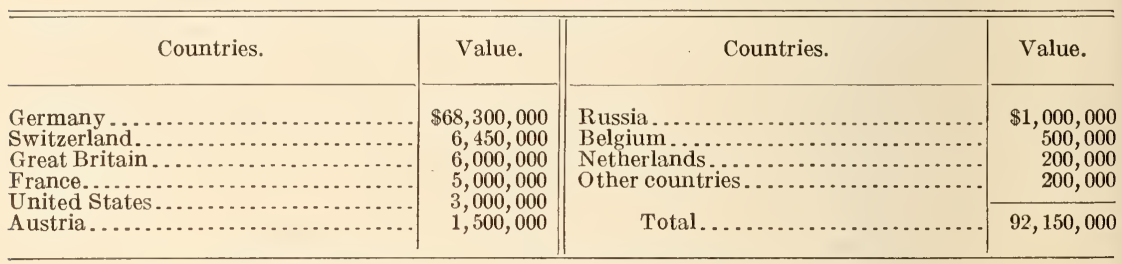

This shows that Germany furnishes 74 per cent, or about threequarters, of the world's dyes.

The production of artificial dyestuffs for exportation is confined practically to Germany, Great Britain, and Switzerland. The values of such exports in 1912 were: Germany, $\$ 48,430,000$, or 88.2 per cent; Switzerland, $\$ 5,450,000$, or 9.9 per cent; Great Britain, $\$ 990,000$, or 1.8 per cent; total value, $\$ 54,870,000$. In the world's markets Germany's domination is evident, Switzerland being practically the only competitor.

'The distribution of Germany's exports of artificial dyestuffs among the different countries is a matter of interest. The exports of finished dyes in 1912 were valued as follows: Aniline dyes, $\$ 31,836,000$; alizarin, $\$ 2,197,000$; anthracene dyes, $\$ 3,429,000$; indigo, $\$ 10,968,000$; total, $\$ 48,430,000$. The following table, compiled by Dr. Bernhard C. Hesse, the well-known chemist and statistician, shows very clearly the present dependence of the various countries upon Germany for their supplies and the importance of the United States as the leading customer. Noteworthy is the enormous consumption of synthetic indigo by China. The table shows the percentage of the exports of each dye taken by the principal consumers.

\begin{tabular}{|c|c|c|c|c|}
\hline Consuming countries. & $\begin{array}{c}\text { Aniline } \\
\text { dyes. }\end{array}$ & Alizarin. & $\begin{array}{l}\text { Anthra- } \\
\text { cene } \\
\text { dyes. }\end{array}$ & Indigo. \\
\hline 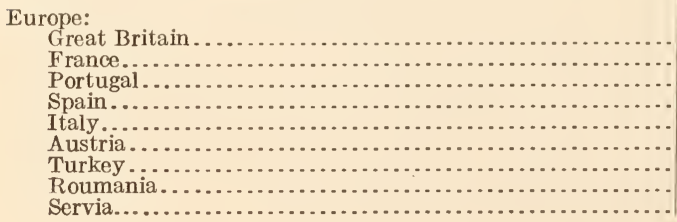 & $\begin{array}{r}\text { Per cent. } \\
17.14 \\
2.15 \\
.65 \\
1.02 \\
6.38 \\
8.99 \\
.68 \\
.35 \\
.15\end{array}$ & 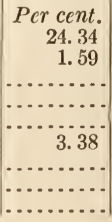 & $\begin{array}{r}\text { Per cent. } \\
23.72 \\
2.52 \\
\ldots . . . \\
0.23 \\
6.80 \\
\ldots \ldots . . .\end{array}$ & $\begin{array}{r}\text { Per cent. } \\
3.54 \\
.97 \\
\ldots \ldots . \\
.20 \\
1.98 \\
4.08 \\
.33 \\
\ldots \ldots . . .\end{array}$ \\
\hline
\end{tabular}




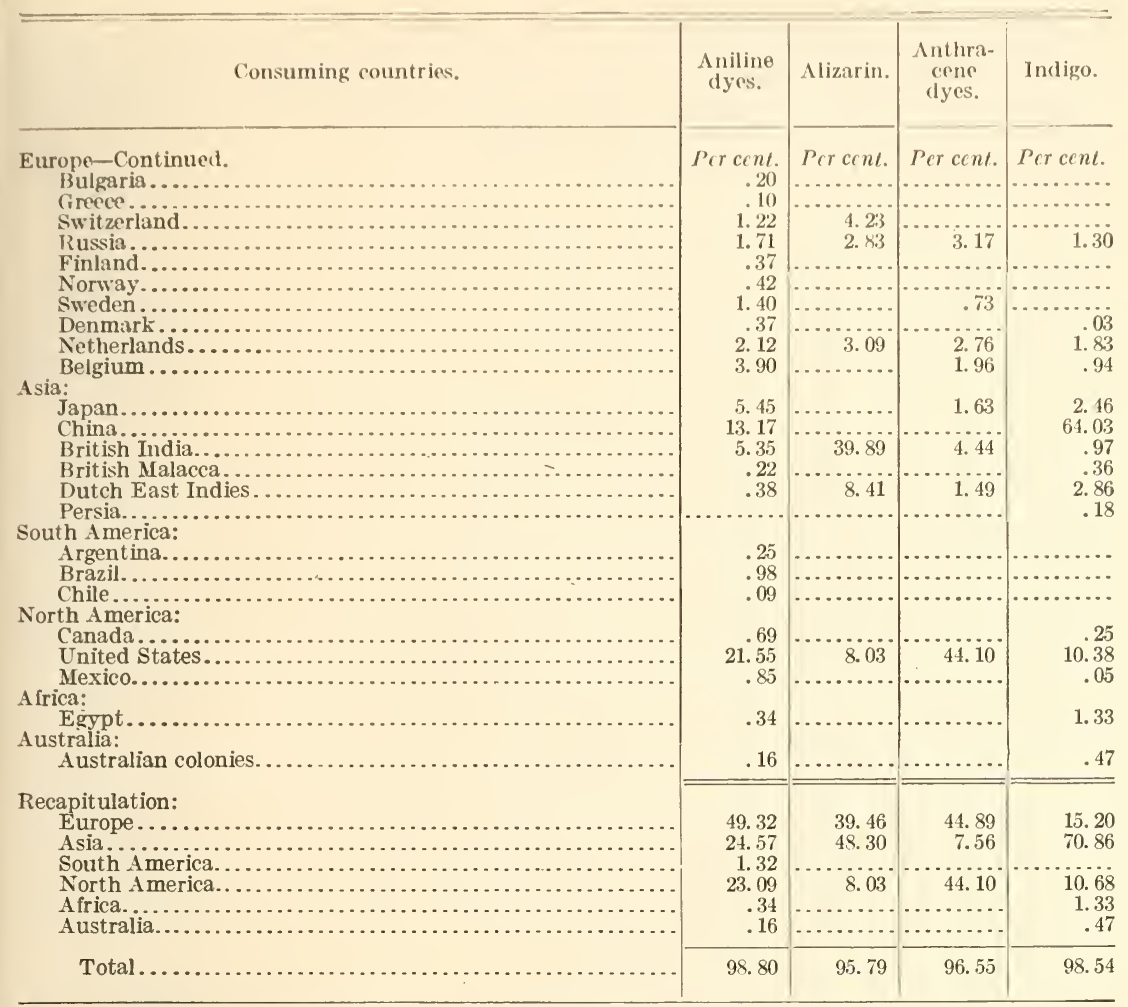

\section{TRADE IN CRUDES AND INTERMEDIATES.}

The domination of the German color industry is, however, greater than would appear from the export statistics for finished dyes. As far as the production of crude coal-tar products is concerned, Germany has been for nearly 20 years practically independent of other countries. Its own tar industry produces, or is capable of producing, all crude compounds needed in the industry. The nearest approach to an exception is in the case of anthracene, the raw material for the manufacture of alizarin and an important class of dyes. There is enough of this hydrocarbon in German tar to meet the needs of the dyestuff works. In England, however, the separation of anthracene from the heavy oil of the tar works has been highly perfected and it is commercially profitable to draw upon the English supply. The independence otherwise of the German production of crudes, and its ability to send supplies to other countries, is shown by the following summary, for 1912, of Germany's trade in crude coal-tar products:

\begin{tabular}{|c|c|c|}
\hline Crudes. & Imports. & Exports. \\
\hline 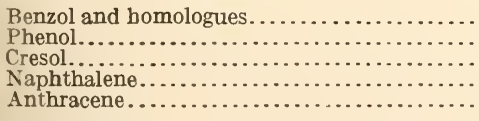 & $\begin{array}{r}\$ 509,000 \\
537,000 \\
7,600 \\
184,000 \\
66,400\end{array}$ & $\begin{array}{r}\$ 1,631,000 \\
852,000 \\
72,007 \\
211,(00) \\
12,000\end{array}$ \\
\hline Total............. & $1,304,000$ & $2,778,000$ \\
\hline
\end{tabular}


Germany's excess of exports is $\$ 1,474,000$.

Much more striking and of far-reaching importance is the revelation of the figures contained in the summary, for 1912, of Germany's trade in intermediate coal-tar products:

\begin{tabular}{|c|c|c|}
\hline & Imports. & Exports. \\
\hline 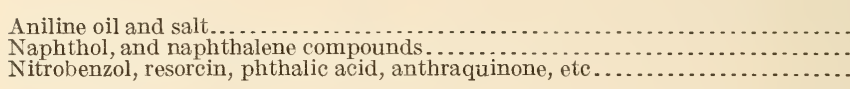 & $\begin{array}{r}\$ 4,000 \\
41,000 \\
107,000\end{array}$ & $\begin{array}{r}\$ 1,559,000 \\
682,000 \\
1,433,000\end{array}$ \\
\hline Total... & 152,000 & $3,674,000$ \\
\hline
\end{tabular}

Here is an excess of $\$ 3,522,000$ in favor of the exports. A calculation based upon the unit prices of the various coal-tar products shows that in a rough approximate way crudes worth $\$ 1$ produce intermediates worth $\$ 3.56$ and finished dyes worth $\$ 7.61$. Assuming that one-half of the excess of exports of crudes and all of the excess of intermediates are used to produce colors in other countries, the value of the dyes manufactured abroad from German products would be, from crudes, $\$ 5,608,000$; from intermediates, $\$ 7,529,000$; total, $\$ 13,137,000$.

These figures show how largely the manufacture of dyes outside of Germany depends upon the industries of that Empire for the primary and intermediate compounds serving as raw materials. The manufacture of artificial dyestuffs outside of Germany has a value of about $\$ 24,000,000$, and over one-half is made with materials from German factories.

The effects of this condition are seen in the trade statistics of other countries. Switzerland's net excess of crudes imported is $\$ 315,000$; of intermediates, $\$ 846,000$. Austria exports a net excess of 3,309 metric tons of crudes, and the net excess of imported intermediates is 1,032 tons. Great Britain exports crudes worth $\$ 2,073,000$, and intermediates worth $\$ 156,000$. British imports of both classesbut chiefly intermediates-are valued at $\$ 758,000$.

Is already noted, nearly all the intermediates employed in manufacturing coal-tar dyestuffs in the United States come from Germany. This is also the case for Belgium, the Netherlands, and Russia, and very largely so for France.

Briefly stated, Germany makes three-quarters of the world's artificial dyes and controls the supply of raw material for one-half of the remaining quarter. Furthermore, for one great class of dyes, the alizarin colors, and for a vast number of minor subdivisions, that country is almost the sole source of supply. It possesses in an exceptional degree a well-known commercial power to influence if not force customers requiring a large variety of dyestuffs to purchase from it all the entire stock needed. The industry is in such a position that it can easily render almost impossible in a given country the production of intermediates or finished dyes, unless prevented by governmental protection or assistance.

The exceptional position of the Swiss industry is due to the fact that it started simultaneously with the German industry, and kept even step with its more powerful neighbor in the different stages of evolution. There are very friendly relations between the leaders in 
the two countries. 'The bulk of the Swiss production is at Basel, on the German frontier. The Swiss industry depends ehiefly on Germany for its intermodiates and for its heavy chemicals; at the same time it does not threaten the supremacy of the German dyestuff trade in the world's markets.

\section{CAUSES OF GERMANY'S SUPIEMACY.}

The actual supremacy of Germany in the production of coal-tar dyes has been outlined above and its dominating position in international commerce clearly shown. It remains to describe how this supremacy has been won and how it is maintained.

The base of the present structure was laid half a century ago when the industry of artificial dyestuffs was still in swaddling clothes. A remarkable number of German chemists of the first rank and of the second rank were attracted to the new industry. The admirably equipped laboratories of the German universities and schools of science were devoted largely to research in the new field. Simultaneously, in Germany, the molecular constitution of the aromatic hydrocarbons was revealed by Kekulé, and a vast amount of scientific knowledge, keen mental effort, high inventive capacity, and patient labor was devoted to applying the new theories to the cliscovery of tinctorial compounds among the derivatives of the aromatic series. A small army of plodding, but still clever, young chemists carried out thousands and thousands of separate researches under the leadership of brilliant men, such as Hoffmann, Bayer, Liebermann, Graebe, Witt, and many others. Far more was done in Germany to develop the possibilities in the province of synthetic dyes than in all the rest of the world. At the same time the young industry was fortunate in securing the generous cooperation of financiers with farsighted courage and technical managers of exceptional sagacity. What is said of Germany is also essentially true of Switzerland but naturally on a more modest scale. The seventies saw the industry well defined and established upon a solid basis, while the progress of discovery continued at an increased rate. The notable triumph of this period was the introduction of synthetic alizarin. During the eighties there was an increased appearance of new classes of important dyes. It was the golden decade. The industry was recognized as one of the great national assets of Germany. In the nineties there was a decided lull in invention. Great attention was devoted to the standardizing of manufacture, and especially to the organization of the foreign trade. Germany became practically independent of the world in regard to its supply of coaltar crudes. The relations between the great manufacturing houses became cordial, and there was a general spirit of cooperation. The manufacture of a large number of valuable medicinals and photographic chemicals from coal-tar intermediates was added to the production of dyestuffs. Great quantities of these intermediates were also employed in the preparation of high explosives. All this contributed to making the industry better balanced and more symmetric, while, of course, adding to its complexity.

The present century has seen a steady development. Synthetic indigo won its great victory. 'The discovery of new types of colors has become rare. Close trade agreements have come into existence, 
with Govermment approval, and have been maintained without difficulty. At present the industry is the most remunerative in the Empire, and the one most conspicuous in international trade as distinctly and predominantly German. It has been created in Germany, and is regarded by Germans as their most brilliant triumph in applying science to industry. The rest of the world generously recognizes the full right of Germany to be justly proud of its accomplishment.

\section{RESEARCH THE CHIEF CAUSE.}

Unquestionably the chief factor in favoring the early start of the industry and its remarkably rapid and harmonious development was the spirit of research in Germany and the marvellous equipment for facilitating, largely at public expense, the exercise of this spirit. While other countries sought to encourage the introduction of new branches of industry by the aid of tariff protection, in Germany manufacturers, capitalists, and Government officials early recognized the creative power and earning capacity of highly organized industrial research. Any marked advance in developing the coal-tar chemical industry in the United States must depend upon the full recognition of this fact, for no other industry is so intimately associated with research of the highest scientific character.

A most competent authority, Dr. B. C. Hesse, says in this connection:

What we do need is a semimanufacturing laboratory in which to ascertain the most favorable conditions for carrying out those operations which the work of the Germans, both in their patents and in their commercial exploitation of them, has shown to be needful or worthy of prosecution. 'That, however, is no child's play task; it calls for engineering skill of the highest order, chemical knowledge of great refinement, and experimental ability of high rank. Much will have to be learned and determined as to the proper materials of construction, the proper size and shape of the apparatus, and the most favorable working unit, which is by no means constant from one dyestuff or one intermediate to another. Many dyestuffs can not be made commercially in lots much greater than 100 pounds; others can be made in lots of 1 ton, but the manufacturing unit, as a rule, is small

GERMAN INDUSTRY, CAPITAL, DIVIDENDS, ETC.

In analyzing the organization of the German dyestuff industry, it will be found that not only a rast amount of brain effort has been expended in its creation but that also the cash investment has been extremely large.

There are now 22 German establishments devoted to the manufacture of coal-tar colors. Of these 21 are owned by joint-stock companies. The combined capitalization of the 21 companies, in 1913, was $\$ 36,700,000$. In that year they paid dividends amounting to $\$ 11,600,000$, or 21.74 per cent of the nominal capitalization.

The explanation of this high percentage lies in the fact that for many years the industry has regularly devoted a large share of its profits to writing off the real estate and plant accounts and to new construction. One of the oldest and strongest companies has a capital of $\$ 13,100,000$. Its stock sells at 600. In 1913 its net profits were $\$ 6,000,000$, nearly one-half of the capital. One-third of this sum was devoted to a sinking fund for the erection of new plants, etc., and to welfare funds for operatives. From the remainder a dividend 
of $2 S$ per cent was paid. This course has been pursued for so many years that it is now estimated that at least $\$ 400,000,000$ have been invested in the industry.

It is worthy of note that the next most remunerative chemical industries in Germany are those deroted to explosives, glass, heary chemicals, metallurgy, soap, and candles. The factories number 252. Dividends range from 11.2 to 11.8 per cent. Most of the remaining chemical industries in the Empire pay dividends of 5 to 10 per cent.

It is easily seen that financially the German coal-tar dye industry is exceptionally woll fortified and in a position to resist powerfully any attempt to destroy its supremacy.

\section{GEOGRAPHY OF THE GERMAN INDUSTRY.}

A marked feature of the industry is its concentration. The plants are all located within an area forming a square, with sides of 300 miles. The actual concentration is even more pronounced, for, with the exception of the big works at Berlin, all the leading establishments, as well as the coke fields supplying the tar and the benzol, are situated on the Rhine and its tributaries, in a narrow strip of territory less than 200 miles in length. This means cheap haulage for the bulkier raw materials and facilities for the economical distribution of finished products by water to all parts of the world.

If an industry of this size in the United States, doing an extensive trans-Atlantic business, were located chiefly along the banks of the Hudson, between Albany and New York, and obtained most of its raw material and fuel supply within short distances from the river, the concentration would be practically the same. These conditions are readily seen in the accompanying map.

\section{RELATIONS BETWEEN COMPANIES.}

The adrantages of this close concentration, permitting easy communication and transfer of products between different factories, are intensified by the close relations between the several companies. Three of the largest organizations are closely allied; three other powerful companies form another combine. The relations between the two big units are, however, friendly, and this is the case also with the relations between the larger and the smaller firms. There is keen competition to maintain high standards of excellence in products and to diminish the cost of production, as well as to bring out new dyestuffs; but there is a well-organized combination to maintain prices and to render mutual assistance in utilizing intermediates and by-products. For practical purposes the industry is a unit, especially in all that concerns its dealings with foreign markets and with foreign attempts at competition. These trade agreements and cooperative arrangements seem to have prevented the appearance of rivals on German soil during recent years. They have made themselves frequently felt on this side of the ocean, as efforts have been exerted from time to time to secure emancipation from dependence upon German intermediates or finished products. 


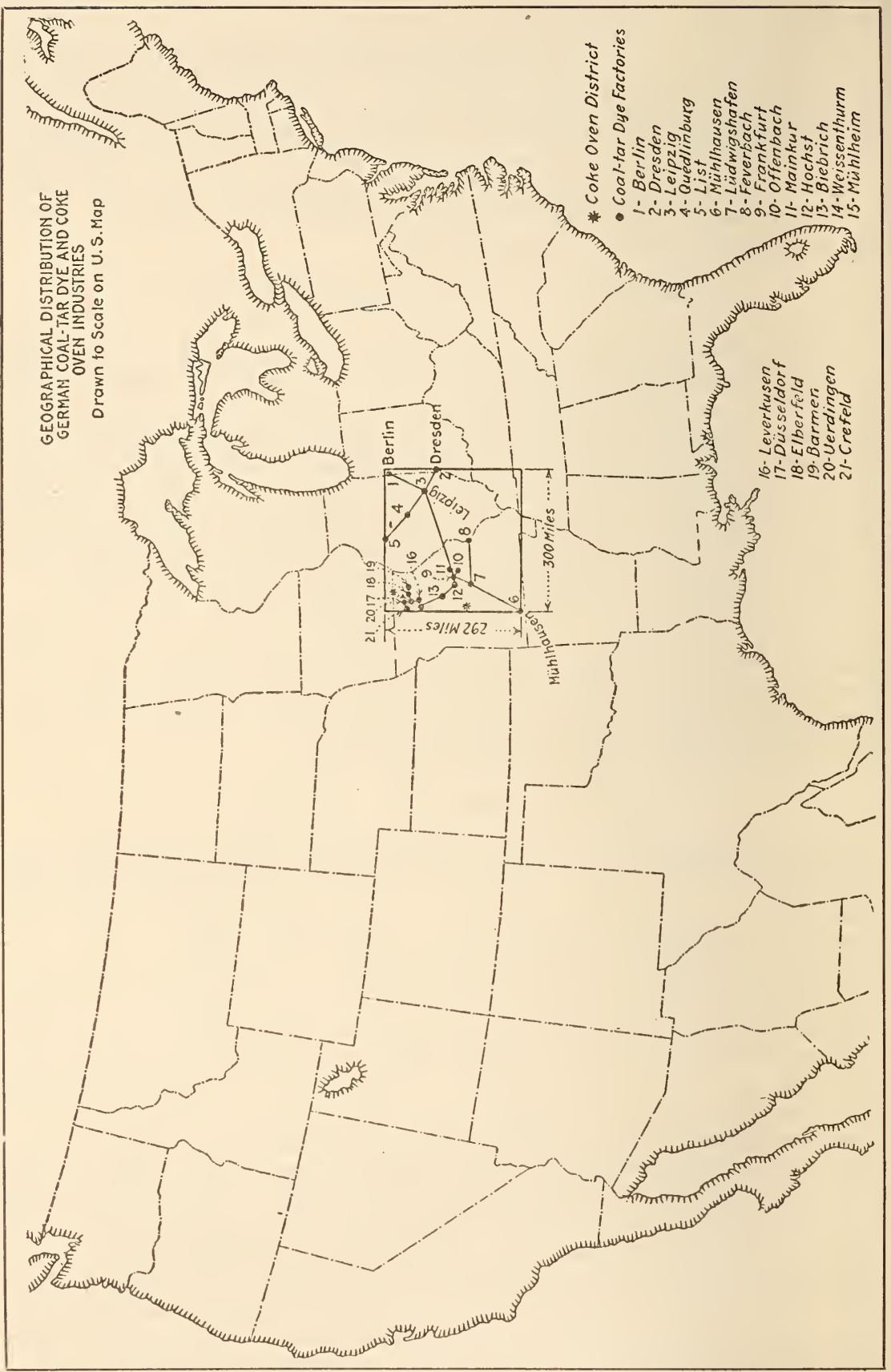




\section{EQUIPMENT OF PLANTS.}

As the general industry has developed, the individual companies have, in several cases, widely extended their operations, so as to manufacture all or nearly all of the intermediates required in their processes and a large share of the heary chemicals needed. They have gone outside the limits of eolor chemistry and manufactured a variety of synthetic medicinal preparations, several synthetic perfumes, and some important photographic chemicals, as well as materials for modern high explosives. This has meant a great diversity of equipment and a delicate adjustment of manufacture, so as to permit the complete utilization of all by-products. In this respect the coal-tar chemical industry shows a marked resemblance to the great American packing industries. Starting with 10 crude coal-tar compounds, it produces a host of raluable articles, but finds methods of utilizing and deriving profit from all its by-products. If any such compounds occur in the erolution of a new product, and threaten waste and loss, they are transformed into other new preparations, for which uses can be created.

All of this inrolves extended application of chemical engineering, and means the employment of a wide range of technical derices.

A couple of examples may be cited as showing the extensire plant and staff and output of German works and the rate of expansion.

The famous "Farbwerke" at Höchst started in 1863 with 5 workmen, making the few aniline dyes then known. By 1888 it employed 1,860 workmen and 57 chemists, and utilized 1,\$40 horsepower in its steam engines. It then produced 1,750 different colors. In $1912,30,000$ horsepower were required. The staff included 7,680 workmen, 374 foremen, 307 chemists, and 74 engineers. Wages amounted to $\$ 2,050,000$, and salaries and bonuses to $\$ 1,240,000$. The number of colors reached 11,000. Synthetic alizarin and indigo were leading products, and such materials as antipyrine, tuberculin, and diphtheria serum were made on a large scale.

A still larger establishment is the Badische Anilin- und Soda Fabrik, near Mannheim on the Rhine. It corers about 500 acres, with a water front of a mile and a half on the Rhine. The buildings corer 100 acres. Transportation between the several hundred buildings is effected by 42 miles of railway. Power is generated and transmitted by 158 boilers, 386 steam engines, and 472 electric motors. Steam fire engines number 25, and there are 400 telephones. Each day there is a consumption of 1,000 tons of coal, 40 tons of ice, $40,000,000$ gallons of water, and 2,500,000 cubic feet of gas. In 1908 workmen numbered 8,000, chemists 217, engineers 142, and the commercial staff 918 .

\section{WAGES IN THE GERMAN FACTORIES.}

The participation of labor in the cost of finished dyes is not high. It ranges from 10 to 15 per cent, and is usually nearer the lower figure. There has been, however, a steady increase in the arerage wage rate of late years. The arerage daily wage in Germany for all labor-boys, and common and skilled labor-was \$0.65 in 1886. In 1908 it had reached $\$ 1.14$, an increase of 77 per cent. In 1906 the arerage daily wage in the Badische works for a 10-hour day was $\$ 1.04$. To the normal wage should be added the contribution by 
employers to the State old-age, accident, and sick funds, bonuses gained by many workmen, and the gifts for general welfare. In the case of the Badische this gift was $\$ 750,000$ in 1908 . Including these various items, it may be assumed that the prevalent adult daily wage in the dyestuff works is now about $\$ 1.80$, as far as the actual outlay by the employers is concerned.

A large item in the cost of production is due to the salaries of well-trained, competent chemists and engineers, who supervise every step of the multitudinous processes. Thus, the "Badische" employs 30 well-equipped chemists-university graduates-in the research laboratory alone, quite apart from the manufacturing staff.

\section{PROCESSES OF MANUFACTURE.}

The chief processes employed in transforming the 10 coal-tar "crudes" into nearly 300 intermediates required for the direct production of dyestuffs are 11 in number. Slightly varied in individual cases, they constitute the great bulk of the operations performed in color works. They are of such fundamental importance that a brief description is desirable in order to bring out clearly the high degree of correlation and coordination that characterizes the industry. These processes are (1) nitration, (2) chlorination, (3) sulphonation, (4) reduction, (5) oxidation, (6) caustic fusion, (7) alkylation (8) liming, (9) condensation, (10) carboxylation, (11) diazotizing and coupling.

(1) Nitration.-An aromatic compound is treated with a mixture of nitric acid and sulphuric acid. As a result usually one, but sometimes two or three, atoms of hydrogen are replaced by the nitro group, $\mathrm{NO}_{2}$. The extent and nature of the reaction are largely effected by the factors of time, temperature, and proportions. Usually the residual, somewhat diluted, sulphuric acid can be concentrated and used repeatedly.

(2) Chlorination.-Action of dry chlorine gas. The gas is usually obtained in connection with the electrolytic production of caustic soda from salt, is liquified for transportation, and allowed to volatilize as needed. The reaction is not so easily controlled as nitration and a variety of substitution products are of ten the result, causing much difficulty in separation. One-half of the chlorine employed is recovered in the form of hydrochloric acid. The synthetic production of indigo involves the use annually of over 5,000 tons of chlorine, prepared simultaneously with nearly 6,000 tons of caustic soda, and yielding, as by-product, nearly 8,000 tons of 33 per cent hydrochloric acid.

(3) Sulphonation.-The action of fuming sulphuric acid, usually in very large excess, to act as a vehicle. The reaction is, in a few cases, easily controlled. In most instances a variety of sulpho-acids are obtained, requiring separation, and involving the problem of utilization. The excess of sulphuric acid is generally lost.

(4) Reduction.-The substitution of hydrogen for oxygen in nitrocompounds, forming the corresponding amido-bodies. Thus, benzol is changed by nitration to nitrobenzol and that, by reduction, to amidobenzol, or aniline. Iron filings or turnings, with acetic or sulphuric acid, form the usual reducing agents. The resultant iron salts are without value. 
(5) Oxidation.-Potassium bichromate, potassium chlorate, lead peroxide, manganeso dioxide or a permanganate, with hydrochloric acid or sulphuric acid, are the usual reagents. The residues, chrome alum, potassium chloride, etc, are all susceptible of utilization.

(6) Caustic fusion.-The operation is performed chiefly with sulpho-acids. As a result the sulpho-group is replaced by hydroxyl. Thus benzol monosulpho-acid, on fusion with caustic soda, gives phenol, or carbolic acid. The residue of sodium sulphite is sometimes used in making bisulphite, more often discarded. The operation is one requiring unusual care, and the results are of ten variable.

(7) Alkylation.- The introduction into hydroxyl or amido groups of the radicals methyl or ethyl, present in wood alcohol and grain alcohol. The alcohols, or methyl or ethyl chloride, are used, along with hydrochloric acid, and the opcration is effected at elevated temperatures under pressure in autoclaves.

(8) Liming. - The use of lime or chalk to effect separations in mixtures, especially of sulpho-acids, through the differing solubilities of the calcium salts. Sometimes the purpose is to decompose chlorides and effect the separation of resultant acids and aldehydes.

(9) Condensation.- A large class of operations in which two molecules of the same substance, or of different substances, unite to form a new compound, with the elimination of water, or ammonia, or hydrochloric acid. Sulphuric acid in considerable excess is the usual condensing agent. When used it reappears as a spent acid, too weak to admit of profitable recovery. Other condensers are the chlorides of zinc, aluminum, antimony, sulphur, and phosphorus. In most cases they can be recovered at slight cost and used repeatedly.

(10) Carboxylation.-The introduction of the acid carboxyl group, by the joint action of caustic soda and carbon dioxide on phenol and its homologues. Thus phenol gives salicylic acid; a-naphthol gives oxy-naphthoic acid. The alkali is recovered in the form of chloride or sulphate.

(11) Diazotizing and coupling.-An aromatic amine reacts with nitrous acid, forming a diazo-compound. Thus aniline yields diazobenzol. Such a diazo-compound in the presence usually of sodium acetate unites readily with a variety of aromatic substances; the operation is termed coupling. The product of such a reaction splits up, yielding the original amine and the amido-derivative of the second substance employed. Thus, salicylic acid, by coupling with a diazo-compound and subsequent reduction, is changed into amidosalicylic acid, an intermediate of widespread use. This sequence of reactions is of prime importance. It serves to produce a variety of intermediates, and is the fundamental operation in the manufacture of the so-called azo dyes, which constitute about one-half of the number of artificial dyes now current in the world's trade.

The purely chemical transformations fail to reveal the full extent of the sequence of operations in eventually obtaining intermediates from crudes by a chain of reactions. Between any two successive chemical changes there are from one to three mechanical operations, such as baking, boiling, filtering, precipitating, blowing off with steam, and the like. There are also minor chemical operations, such as the change of acids or bases into salts; the separation of salts from liquids; their purification, drying, and storing, etc. 
In the preparation of about 300 intermediates by the use of these 11 classes of reactions there is encountered the greatest diversity of problems to be handled. Every step involves the production of compounds other than the one mainly sought. How to limit their appearance so far as possible, how to utilize them when inevitably formed, how to adjust and balance the consumption of all the products, are problems that demand exceptional technical and business ability and the closest cooperation between the manufacturing and the commercial staffs of an organization.

\section{UNIFORMITY OF PRODUCT.}

One of the most serious demands on the technical staff of a dyestuff factory is the necessity of obtaining the highest uniformity in finished products. Standards of purity are now very rigid. Purchased dyes are subjected to severe tests. This means great refinement and exactitude at every stage of the process in the evolution of a dyestuff. Exhaustive and careful tests are essential at each step before an intermediate can be submitted to a new chemical transformation. The margin allowed for variation from the standard of purity is very slight. In some instances the presence in a given intermediate of as little as one-fifth of 1 per cent of a closely allied compound, formed simultaneously in its production, would be prohibitive to its further use.

All of this adds to the complexity of the manufacturing problem. In fact, at every stage the artificial-dyestuff industry presents a marvelous maze of materials and operations, interdependent and closely interlocked technically and economically.

\section{TYPICAL PHASES.}

The astounding complexity of the manufacture as a whole has recently been set forth in a very striking and clear manner by Dr. B. C. Hesse, in comprehensive presentations of the entire series of operations involved in the production of certain classes of dyes. With his permission summaries of some of the more striking phases of manufacture, as admirably outlined by him, are presented.

The current types of dyes now number 921. Each one, as a rule, is offered commercially in a variety of brands, differing minutely from each other in exact shade, or in the availability for use with certain textiles. There are thus many thousand distinct brands for sale.

These 921 dyes are divided into 17 separate chemical classes, as shown in the table that follows:

\begin{tabular}{|c|c|c|c|}
\hline Classes of dyes. & $\begin{array}{l}\text { Number } \\
\text { of types. }\end{array}$ & Classes of dyes. & $\begin{array}{l}\text { Number } \\
\text { of types. }\end{array}$ \\
\hline 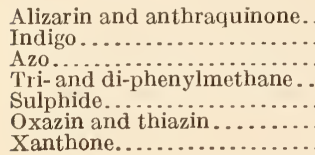 & $\begin{array}{r}116 \\
48 \\
462 \\
73 \\
52 \\
48 \\
34\end{array}$ & 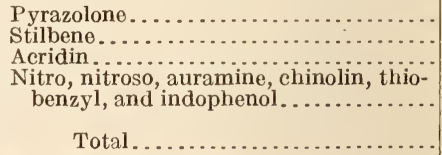 & $\begin{array}{r}12 \\
10 \\
8 \\
20\end{array}$ \\
\hline
\end{tabular}




\section{ILLUSTRATIVE OUTLINES.}

Alizarin, NAPHTHOL, Yellow, MAGENTA.

Some of the simpler types of production may first be presented. Crudes, intermediates, and final dyes are distinguished by capitals. Operations are in parentheses.

Sequence of operations in alizarin manufacture:

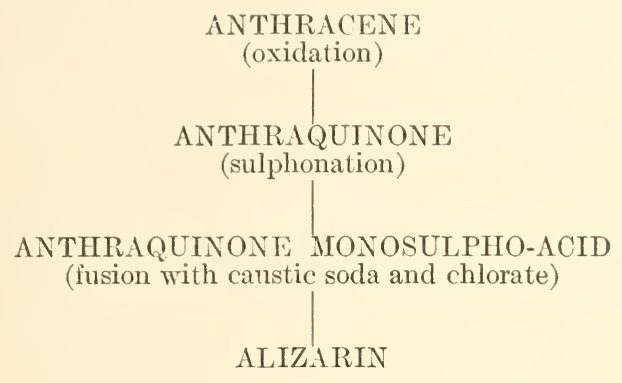

There are here only three chemical transformations. The anthraquinone serves also as the starting point for a variety of important dyes. Alizarin has been the source of a vast amount of wealth to Germany since its discovery in 1869 , when it began to supersede madder. The patent rights expired in 1886, but its manufacture has never been attempted in the United States.

Operations in manufacture of naphthol yellow:

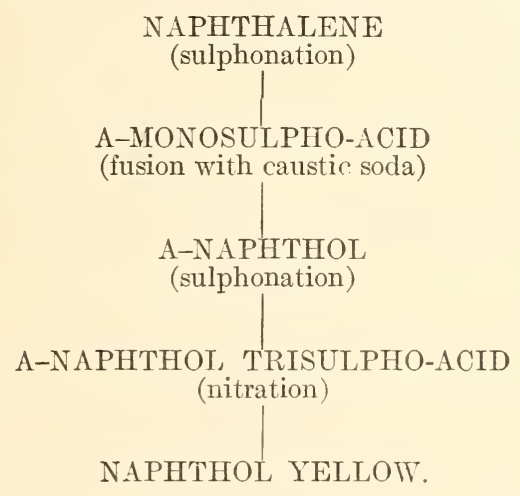

This is one of the earlier standard dyes. Patent rights expired in 1897. Some has been manufactured in this country from imported a-naphthol trisulpho-acid, the last transformation being comparatively easy. Practically none is made here. 
Operations in manufacture of magenta:

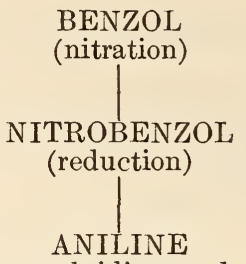

(reaction with o- and p- toluidine, and o- and p- nitrotoluol)

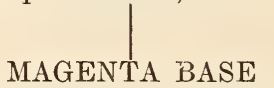

(treatment with hydrochloric acid)

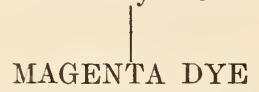

Preparation of nitrotoluol and toluidine:

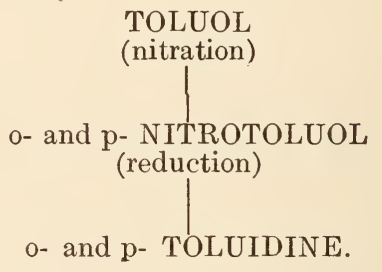

Magenta is a dyestuff largely used in the United States. It is made here to some extent, but the manufacture is confined to the final step, the action of hydrochloric acid on the magenta base. In $\$ 1,000$ worth of magenta the hydrochloric acid participates to the extent of about $\$ 5.50$.

\section{HYDROQUINONE AND SYNTHETIC INDIGO.}

Following are the operations in the manufacture of hydroquinone:

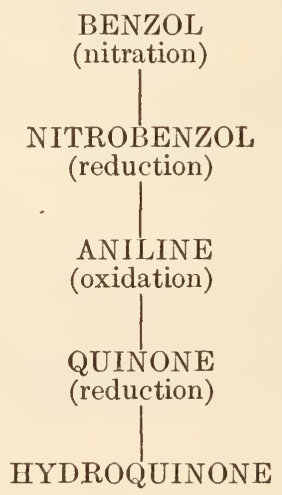

Hydroquinone, while not a dye, is used in great amounts as a photographic developer, and is an important accessory product of German factories. It is made to some extent in the United States from imported or domestic aniline. 
There are four methods of making indigo. Three start from benzol and the fourth from naphthalene.

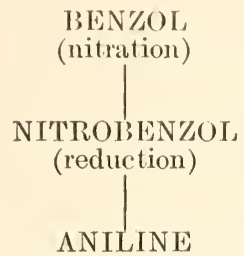

(treatment with chlor-acetic acid)

PHENYL GLYCINE

(fusion with sodium oxide)

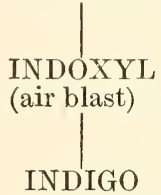

The crucial point in the sequence is the transformation of phenyl glycine into indoxyl. An older method used fusion with caustic soda. The yield was about 45 per cent. A later process made use of sodium amide, with nearly quantitative results. A still later process substituted advantageously sodium oxide for the amide.

The manufacture from naphthalene is slightly more involved:

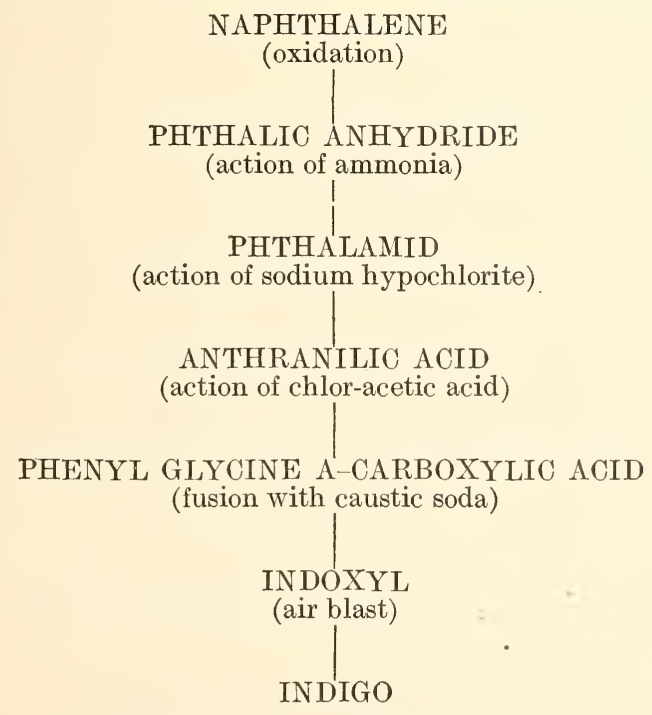

The development of this industry illustrates the influence of quantities. This last method was the first to be used successfully on a commercial basis. This was due primarily to the fact that at that time, by fusion with caustic, 90 per cent of the phenyl glycine compound could be changed into indoxyl. It was also largely due to the fact that naphthalene could be had in abundance, and was sceking a market. Pure benzol could be secured, but the preparation of 
the vast quantity of pure benzol needed for the world's consumption of indigo would have entailed the simultaneous production of a very large amount of toluol, for which there was at the time no visible demand. Naphthalene could be employed without involving the production of other coal-tar crudes. Gradually new uses for toluol have been found, and more and more pure benzol is available at low rates. Probably the manufacture of indigo will soon be based entirely upon the use of benzol as the primary material.

The history of this manufacture illustrates how intimately commercial conditions control the choice of materials in the dyestuff industry, and how in all branches a certain "balance of power" must be maintained in order to assure the highest economic results. It is interesting to note that the first step in the naphthalene process involves the use of sulphuric anhydride representing the annual consumption of 80,000 tons of 50 per cent pyrites. The chlor-acetic acid employed represents an annual consumption of 4,500 tons of glacial acetic acid, and 5,000 tons of liquid chlorine.

\section{THE KETONE DYES.}

To illustrate operations on a more varied scale, the group of socalled ketone dyes may advantageously be summarized. These are closely related chemically, include representatives from several of the 17 classes, and show how these classes are interlaced and interlocked with one another. The 24 dyes in this group constitute onefortieth of the total number of current dyes. They are all good sellers. Most have been in use 30 years. Eight were never patented in our country. American patents have expired on eleven, and will expire on four in the course of a year, and on a fifth in 1925.

The common material employed in making each of the 24 dyes is termed "Michler's ketone." It is obtained by the reaction of carbonyl chloride on dimethyl aniline. The latter is made from aniline, aniline salt, and wood alcohol. Aniline, as already noted, is made from benzol by nitration and reduction of the resultant nitrobenzol.

Carbonyl chloride results from the reaction between carbon monoxide and chloride in the presence of a contact agent, such as platinum or animal charcoal. In a current process of manufacture, calcium chloride, lime, and coke are heated in an electric furnace. The carbonyl chloride gas evolved is condensed to a liquid at $8^{\circ} \mathrm{C}$. The gas is passed into liquid dimethyl aniline until the weight has increased 40 per cent. The reaction is completed by heating for several hours at $100^{\circ} \mathrm{C}$. The resultant ketone is a solid, melting at $174^{\circ} \mathrm{C}$.

By using grain alcohol instead of wood alcohol the corresponding ethyl compound is secured. This is used by preference in a few cases.

In the reaction between carbonyl chloride and dimethyl aniline 21.2 pounds of hydrochloric-acid gas are released for every 100 pounds of ketone formed.

In making dyes by the aid of ketone, "condensation" takes place. The ketone and another coal-tar derivative react upon each other in the presence of phosphorus trichloride or phosphorus oxychloride. The complex dye results, and hydrochloric acid and phosphoric acid are by-products. The latter can be changed again into phosphorus oxychloride for renewed use. 
In making 100 pounds of ketone and in using it to produce dyes, a total amount of 100 pounds of 33 per cent hydrochloric acid is released. Of this about 30 pounds are utilized to prepare salts of basic dyes produced. 'The remainder is arailable for other purposes.

In making and using the ketone, four of the eleven general operations required in dye manufacture come into play, viz, nitration, reduction, alkylation, and condensation. The materials employed are benzol, coke, phosphorus, chlorine, nitric acid, sulphuric acid, hydrochloric acid, iron filings. Intermediates formed are nitrobenzol, aniline, dimethyl aniline, carbonyl chloride.

'Turning now to the production of the 24 dyes in question, it is found that 23 final intermediates are necessary. 'The total number of operations requisite to produce these final intermediates, starting in each case from coal-tar crudes, is 118. Deriratires of benzol, toluol, naphthalene, and phenol appear in the combinations effected. In 16 cases a single coal-tar crude is represented; in the remaining cases, two are present. On an average 5 transformations are required to produce a final intermediate ready to condense with ketone. Reduction occurs 31 times, nitration 21 times, sulphonation 13 times, oxidation 12 times, condensation 11 times, etc.

If equal amounts of ketone were used to manufacture the 24 dyes, using in each case 100 pounds, the total 2,400 pounds of ketone would produce 4,605 pounds of finished dyes. In this final product different constituents would participate as follows: Ketone, 52.11 per cent; benzol, 7.58 per cent; toluol, 5.21 per cent; naphthalene, 11.42 per cent; phenol, 1.69 per cent; from sulphonation, alkylation, etc., 21.99 per cent. Benzol, howerer, constitutes 58.21 per cent of the ketone used, so that the total participation of this hydrocarbon in the dyes would arerage 37.91 per cent.

Naturally these 24 dyes are not required by the trade in approximately equal amounts. In constructing a plant for their manufacture a high degree of intelligence is imperatice, in order to aroid waste of time, space, and apparatus, in planning the size and relative position of the different buildings.

To effect the 118 operations it is not necessary to have that number of sets of apparatus. The 11 major operations require, howerer, in each case, equipment varying in size, etc., depending upon the materials to be transformed, their relative amounts, the time for manufacture, etc. Thus the same apparatus for nitration is not necessarily adapted for use with both benzol and naphthalene, the same condensation apparatus is not applicable for all forms of condensation, etc.

In the manufacture of this group of 24 dyes there are sereral instances where operations produce two or more products, usually isomeric compounds, and the problem of complete utilization is presented.

When chlorine acts upon toluol, three substances, in varying proportions, are always formed-benzal chloride, benzyl chloride, benzotrichloride. Benzyl chloride serves in producing 3 dyes, and benzotrichloride 1 dye, in the group of 24. Benzal chloride is not utilized in this group, but it serres as the starting point for the manufacture of a much larger group-the benzaldehyde dyes. Again in nitrating toluol, two isomeric products are always formed-orthonitrotoluol and paranitrotoluol. The latter is used in making one dye of the 
group in question. The ortho variety is, however, of much greater general importance. It is the starting point for making tolidine, the essential constituent in a group of 45 dyes. The use of the para form in this case, is the utilization of a by-product unavoidably occurring in another branch of manufacture, with the consequent avoidance of waste and loss.

The two instances illustrate how the commercial side of the industry must constantly be on the alert to keep all the intermediate products in alignment, with avoidance of excess production over market requirements. This merchandizing effort involves infinite painstaking and highly developed skill.

The group of 24 dyes includes 15 acid and 9 basic products. Further, 7 are used on cotton, 11 on silk, 17 on wool, and 5 more on wool with the aid of the chrome process. One is employed in calico printing; another is largely used for paper, leather, jute, artificial silk, coconut fiber, and lakes.

As a whole, this group, although involving such a measure of interlocking and interdependence, as shown in the accompanying chart, presents the simplest and least intricate series of relationships in the industry. Other groups show much greater complexity, chemically, technically, and commercially.

BENZIDINE DYES.

A larger and more complex group is that of the benzidine dyes, numbering 82 . The common constituent here is benzidine, a benzol derivative. The formation is as follows:

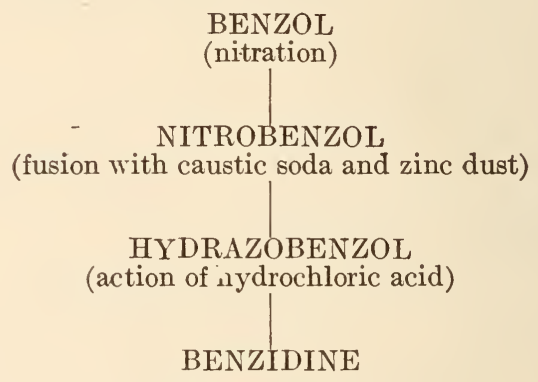

Like Michler's ketone, benzidine itself is not a dyestuff. It is only in combination with other coal-tar derivatives that it gives rise to color products. In order to effect any such combination the benzidine is first changed by the action of nitrous acid into its tetrazo derivative. In this form it reacts with some 44 intermediates to produce 82 current dyes. These 44 final intermediates are derived from benzol, toluol, xylol, phenol, cresol, and naphthalene. Their preparation calls for the production of 55 other intermediates, not used for direct reaction with tetrazobenzidine. The derivation is: Benzol 10, toluol 2, xylol 1, phenol 1, cresol 2, naphthalene 28 .

In combining benzidine with the 44 compounds, to produce the 82 dyes, the latter are used two at a time, three at a time, four at a time, or each one twice. Evidently, from the possible permutations and combinations, a host of differing tinctorial products can be derived from the 44 final intermediates. Of the multitude, but 82 have won a recognized position in the field of dyeing. 


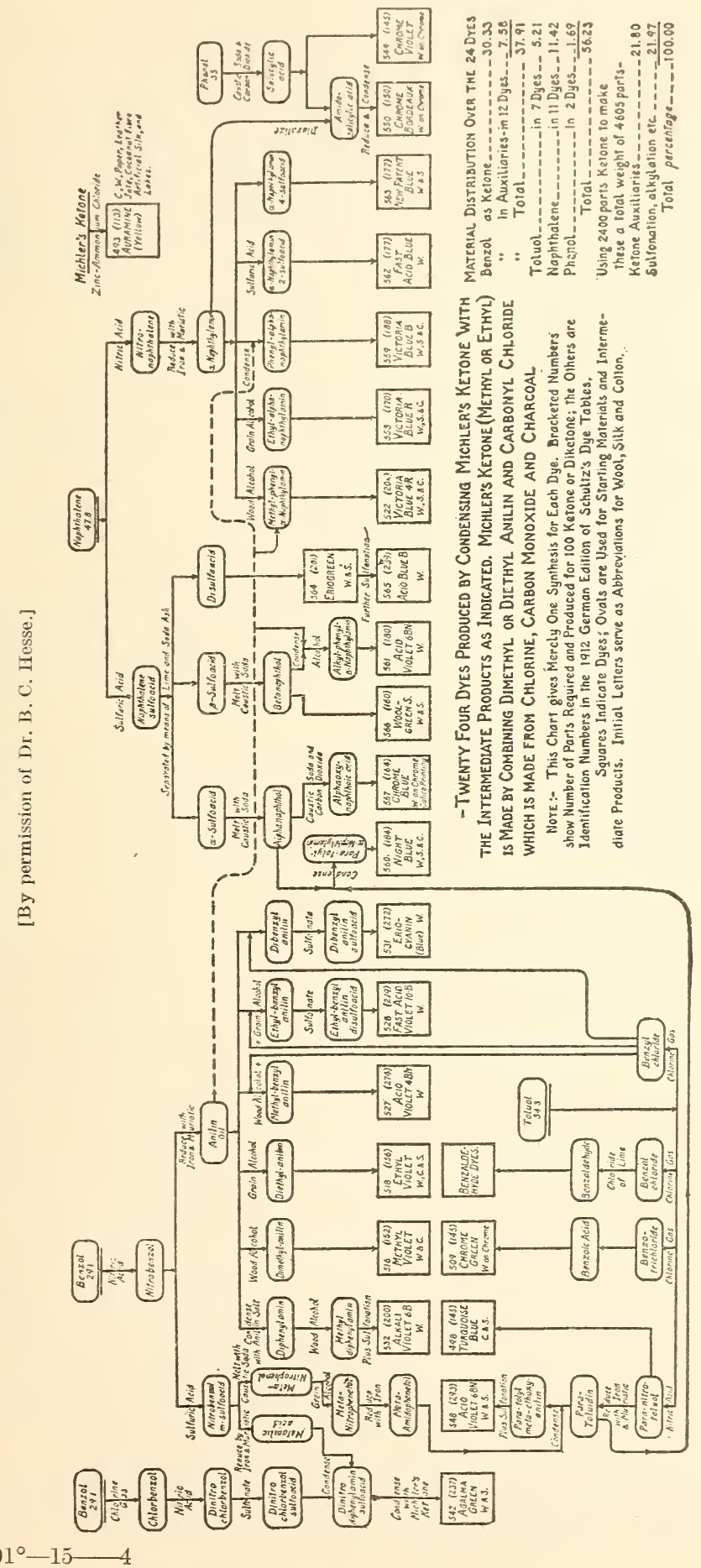


The average number of transformations required to make final intermediates from naphthalene is 4.5 , from the other crudes 3 . As the operations requisite to prepare tetrazobenzidine and its final reaction with one to four intermediates are 5 in number, the total number of chemical changes involved in the manufacture of benzidine dyes ranges from a minimum of 6 to a maximum of 23 . The interdependence is illustrated by the two accompanying charts.

Benzidine dyes are of prime importance, as they dye cotton directly without the use of a mordant. The range of colors and shades is, however, inadequate to meet the demands of cotton dyers.

\section{TOLIDINE AND ALLIED DYES.}

In order to fill in the lacking tints, recourse is had to tolidine, dianisidine, and five other less important derivatives of benzidine. Together these yield the 167 direct cotton dyes, of the so-called diphenyl type, now in current use. They are divided as follows: Benzidine 82, tolidine 43, dianisidine 28, a-nitrobenzidine 1, dichlorbenzidine 3 , benzidine-monosulpho-acid 2, benzidine-disulpho-acid 4, ethoxy-benzidine 4.

These complementary substances are used exactly as benzidine itself, reacting in the same way with the 44 final intermediates already mentioned. They require, however, for the production of several current dyes, a number of additional finished intermediates, more or less complicated in their relationship. They react also directly with phenol and cresol.

Tolidine is made from o-nitrotoluol in the same manner as benzidine is prepared from nitrobenzol.

Together, the dyes of the ketone, benzidine, tolidine, etc., types form about one-fifth of the current artificial colors.

\section{PATENTS IN THE GERMAN INDUSTRY.}

Patents have been multitudinous in connection with the evolution of the German coal-tal dyestuff industry. From 1876 to 1912 they numbered 8,062, or 224 annually on an average. Many corresponding patents were taken out in other lands, especially in France and Great Britain. The number in the United States was 2,432.

But very few of the important intermediates have been patented. Not a few dyestuffs have been patented by non-German inventors. Most patents cover a vast range of possibilities, and protect the manufacture of thousands of theoretical dyestuffs, of which an infinitesimal number ever win a place in the world's markets. It is claimed with authority that not over 1 per cent of the German patents in this industry have ever proved remunerative. In the case of the 921 dyes in current use at the beginning of 1913, 762 German patents were involved. Of these, 485 were originally patented in the United States. One-half of the American patents have expired. Many of the remaining patents expire this year or in the immediate future. Over 50 per cent of the current dyestuffs were never patented in the United States.

The general situation shows clearly that, as far as patent protection is concerned, numerous dyes have been patented by non-German 


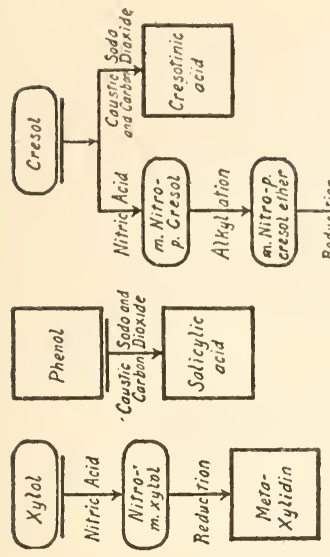

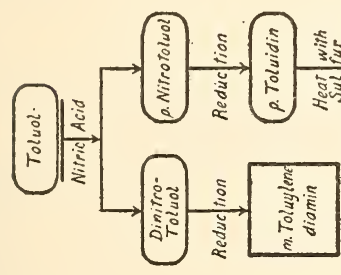

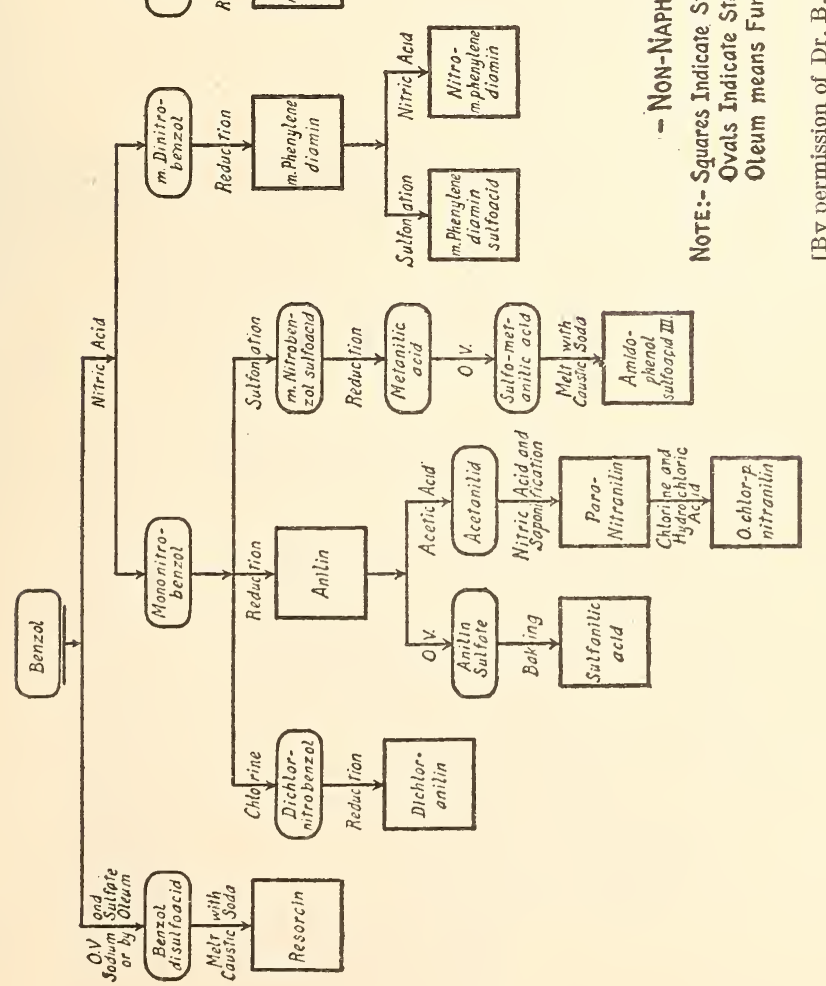




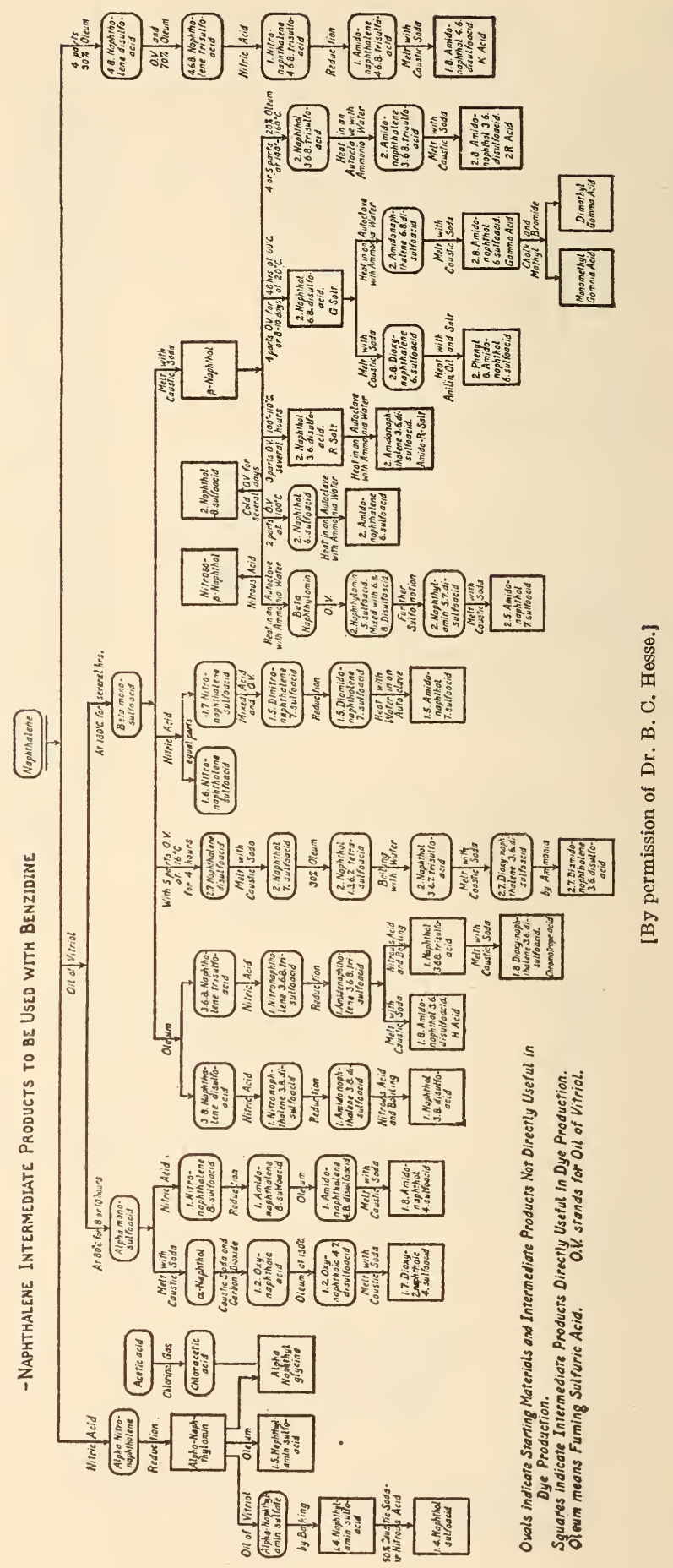


inventors, that many dyestufis have never been patented, that the patents on many others have expired, a considerable number each year, since 18s0. In spite of all this apparent freedom, and the absence of all patent protection on the production of the intermediates requisite for dyestuff manufacture, efforts in other countries to chatlenge and contest Germany's dominant position in the dyestuff industry have been few, and practically futile.

As a matter of fact, Germany has demonstrated her ability to outrank the entire world in making patentable compounds from nonpatented intermediates and, in addition, to manufacture these intermediates in open competition with all rivals.

In its ultimate analysis, the situation shows that German chemists and captains of industry have actually done the bulk of the hard and complicated labor inherent in the creation and organization of a vast branch of manufacture, and that they have not hesitated to use the power associated with its hardly won national predominance to prevent effectively any serious competition in industrial lands.

\section{AMERICAN ATTITUDE TOWARD THE GERMAN INDUSTRY.}

The inquiry why the natural resources of our country have never been utilized on any extensive scale to meet the needs of American consumers and create a distinctly American coal-tar chemical industry has often been raised.

The few American manufacturers of artificial dyestuffs claimed that they were doing all that was possible under existing economic and fiscal conditions. Consumers of dyestuffs were, as a rule, indifferent, satisfied to receive regularly a supply of all needed colors, ordinarily uniform in strength and meeting every possible requirement in shade or adaptability to fabric and material. American economists dwelt upon the enormous complexity of the problem, bristling with difficulties at every step, should any attempt be made to dispute the supremacy of the foreign industry, intricate and complicated beyond any other organized field of human effort and formidably intrenched within the limits of a single powerful nation.

No direct, concrete attempt was ever made to focus national thought in the United States upon the problem, to enlist the cooperation and combined effort of producers of crude products, actual or potential manufacturers of finished dyes, the many trades consuming dyestuffs in quantity, the still more numerous branches dependent in turn upon them, and the general industrial world in seeking an effective solution worthy of the nation's rank.

The present crisis in the world's affairs, threatening to interrupt any day the customary supply of artificial dyestuffs, has served to awaken general attention to the importance of this national question to a degree never attained by the more or less academic discussions of the past. A famine in dyestuffs strikes at the very existence and profitable continuance of a large group of industries. American chemists have been put in the position of defending themselves, and explaining why they could not, at once, meet the Nation's need in an emergency. 


\section{PRODUCERS OF COAL-TAR CRUDES.}

Those in control of our coking interests, and controlling the coal-tar branch, are thoroughly sympathetic to any prospective enlargement of the demand for coal-tar crudes. Recovery plants for benzol and tar in coke works will be rapidly increased, tar distilleries will erect the requisite plant for an ample supply of the requisite 10 coal-tar crudes, just as soon as there is the fairly permanent assurance of a regular demand for the products.

\section{MANUFACTURERS OF HEAVY CHEMICALS.}

These likewise are thoroughly in sympathy with the creation of a large industry, capable of using great amounts of staple chemicals. There does not seem to be any inclination on the part of such manufacturers to embark themselves in the production of dyestuffs. There is, however, a distinct readiness to cooperate, by organizing, on a modest scale, the manufacture of the leading intermediates. One firm has ventured to erect a somewhat extensive plant, after successfully establishing the manufacture of a few intermediates of recognized purity. The feeling here is, however, conservative. There is a marked disinclination to invest considerable amounts, while the danger is present of awakening sooner or later the determination on the part of the German industry to throttle any too ambitious attempts by effective and persistent selling at prices under cost. With the assurance of adequate legislative protection against the danger of "dumping" on the part of foreign producers of coal-tar intermediates, there is every indication that existing chemical industries would embark readily and extensively in the production of this class of compounds.

Hydroquinone, the well-known photographic developer, falling practically in this category of coal-tar compounds, although not used in the production of colors, is now successfully manufactured by an American chemical firm.

\section{MANUFACTURERS OF ARTIFICIAL DYESTUFFS.}

In this class there is no question of a readiness to advance far beyond the modest limits of the present manufacture as soon as adequate legislation is assured. The manufacturers assert that 90 per cent, by value, of the artificial colors used in the United States are now unprotected by patents, or will be freed from patent protection within two or three years; and, further, that practically all of the genuine needs of American colorists are covered by this 90 per cent of dyes.

With the protection of an effective antidumping clause, they feel that much can be done toward building up the dyestuff industry in our country. The manufacture of the simpler intermediates, and of finished dyes involving a minimum of chemical transformations, could be attempted with a degree of security and confidence now unknown.

The certainty that ruthless and prolonged underselling on the part of foreign competition could be effectually forestalled would undoubtedly stimulate effort in several directions and aid in gradually building up important features of the industry, even if there could be 
no attempt at creating a self-contained, national, dyestuff industry in the immediate future. Instances are cited where such an extension of the range of manufacture of intermediates and of finished dyes would unquestionably take place. Among these are such important intermediates as nitrobenzol, aniline oil, and salts, resorcin, nitrophenol, salicylic acid, benzaldehyde, phthalic acid, the naphthols and the naphthylamines. Among the finished dyes are a variety of colors obtained by not more than two transformations from the above list.

'There is some feeling, in this connection, among our dyestuff manufacturers that the patent laws could advantageously be modified, so as to assure the working on American soil of all patents granted by our Government. Great Britain has lately made changes in this direction in her patent laws. Germany has for years required that the owners of a patent must work the invention to an adequate extent in the Empire or do all that is necessary to secure such working. Otherwise, if deemed needful in the public interest, permission is granted others to use the invention. The owner of the patent receives adequate compensation, and the manufacture in Germany is assured. It is claimed that if such legislation had been in force 30 to 40 years ago, when invention in the dyestuff industry was at its height, European patentees would have been forced to build branch factories in the United States. These factories would undoubtedly have developed other products. While not helping the then existing American factories, a large dyestuff industry would inevitably have been created on American soil, with resultant benefit to the country at large.

The general opinion among American chemists and inventors in this field is antagonistic to such legislation. Its evils, it is claimed, more than counterbalance the advantages. Certainly in England it has not aided in the development of the artificial-dyestuff industry.

\section{CONSUMERS OF ARTIFICIAL DYESTUFFS.}

The great textile branches and the other branches consuming large amounts of dyestuffs have been indifferent or lukewarm in the past to the question of an American color industry. Now that their normal manufacture is threatened by dislocation, they are more keenly alive to the vital character of the subject. The chairman of the dyestuffs committee of the National Association of Finishers of Cotton Products, A. L. Lustig, lately stated in this connection: "The textile finisher would have to sacrifice temporarily in some directions in order to accomplish the greatest good for all, which would be a gradual development of the coal-tar chemical industry in the United States. I feel that it would be good business judgment on our part to bear additional financial burdens for some years to come in order to help to establish an American coal-tar chemical industry and in this way ultimately benefit ourselves."

Mr. Lustig is strongly of the opinion that by cooperation between the American manufacturing interests and the German color makers much could be accomplished, that we could gain years of time, save large sums of money, and establish the industry under the most favorable conditions. He adds: "The German people will require all their financial resources to repair the damages caused by the present 
war; but they can furnish us with patent licenses and with some experts, which would form a nucleus for the elaborate steps needed to work out this problem. I believe that by the resulting cooperation with the European manufacturers who, at the proper moment, might be induced to enter this field, we could help to establish the industry here, and in this manner prevent a recurrence of the conditions which jeopardize textile interests at the present time; this might be done irrespective of material changes in our patent laws, changes of tariff, etc."

Some consumers of dyes in quantities, and absolutely dependent upon certain colors unobtainable at present, have erected emergency plants and produce the needed dyes at some considerable increase in cost. In one such case the experiment has worked so well that the manufacturing company has expressed its readiness to embark extensively in the industry and enlarge steadily its present modest plant, if sure of the needed legislation generally demanded.

There is a distinct dread on the part of some users of dyes in regard to identifying themselves with any concerted move to favor the establishment of an American dyestuff industry. They state frankly that any such action would probably result in their being promptly blacklisted by all importers of colors and cut off from any supply of dyes, outside of the limited American product.

\section{ECONOMISTS.}

There is a growing Ieeling among American economists that the time is ripe for reaching a decision whether the United States is ever to have a coal-tar chemical industry, self-contained and independent, utilizing the great natural resources and meeting the Nation's needs, as fully as is the case with our iron and steel industry or a score of other prominent phases of national activity. It is pointed out with force that every year which elapses strengthens relatively and absolutely Germany's predominance in this field and multiplies in geometrical ratio the difficulties to be overcome should the attempt ever be made to create the fully equipped American industry. There seems to be no doubt in the minds of some American economists that the task can be accomplished, and that the present world's conjuncture offers the most favorable opportunity for taking the initial and fundamental steps. The enactment of legislation to prevent "dumping" would unquestionably give an enormous impetus to American enterprise and capital, already attracted to this field. But some years must inevitably elapse before a scientific and technical staff could be thoroughly trained and before such captains of industry could be evolved, as in our iron, steel, petroleum, electrical, and other great industries, peers of their foreign rivals, and often recognized as world leaders.

\section{AMERICAN CHEMICAL SOCIETY, NEW YORK SECTION.}

To meet a widespread demand for explanation, a committee was appointed by the New York section of the American Chemical Society to report upon the situation. This committee was composed of the following members: J. B. Herreshoff, representing the manufacturers of heavy chemicals; I. F. Stone, representing manufacturers of coal-tar colors; J. Merritt Matthews, representing the textile inter- 
ests; H. A. Metz, representing the importers; David W. Jayne, representing the producers of crude coal-tar products; Allen Rogers, chairman of the New York section; and Bernhard C. Hesse, chemical expert, chairman.

The findings of this committee were considered on November 9 , 1914, in detail, and after discussion the report was unanimously adopted by the section.

'The committee's conclusions were in harmony with the general expression of opinion on the part of those more closely concerned with the question, consumers, manufacturers, and others, as just outlined. Special stress was laid in the report upon the imperative necessity of adequate legislation to prevent "dumping," or underselling, by the present dominant foreign industry before any serious attempt could be made to materially enlarge the existing scope of American dyestuff manufacture.

\section{ESTABLISHMENT OF AN AMERICAN INDUSTRY.}

The successive steps necessary for the establishment of a self-contained American coal-tar chemical industry, under favoring conditions, have been outlined as follows:

1. Determination of the American, demand for dyestuffs. - Statistics show the total value of our imports of foreign dyes, but they do not show the exact amounts of each dye consumed in the United States except approximately for alizarin and indigo. It is necessary to take a census in order to have the data for planning intelligently the different phases of a combined manufacture destined to supply the entire domestic demand, and for so coordinating the various features, as to secure the highest economy. This is not an easy matter, but it is indispensable. The information might be secured by a general communication on the part of American consumers of the average annual amounts required of each dyestuff. It might be obtained through a careful collocation of the data contained in consular invoices. Certainly it will never be communicated by importers.

2. Research laboratory.-All interested parties should unite, possibly with Federal cooperation, in the establishment of a research laboratory in which the various chemical, mechanical, and engineering problems connected with the formation of each intermediate and the production of each finished dye could all be solved and standardized. Further, in such an experimental institute the entire coordination of the industry, on the basis of evenly supplying American consumption, could be carefully determined.

3. Evolution of the productive industry.-Simultaneously with the organization of such a laboratory, existing and newly formed factories could start units of production, beginning with the simpler dyes, or those involving a minimum of transformations. Gradually the volume would increase, until finally the entire field would be covered. The central research laboratory would constantly serve as a clearing house to plan and provide against waste through improper coordination; and such cordial trade cooperation as exists between the component parts of the German industry should be sought for. At the same time our schools of science would organize special courses to train up the necessary corps of chemists and chemical engineers to man the growing industry, exactly as they have done for the extensive dyeing and bleaching industries of our country. 
It would take a decade, possibly less, before the industry could meet the great bulk of American needs; but it would be distinctly a national industry. Here and there a minor gap must be filled from abroad until patent rights have expired. Unquestionably American inventive genius would be spurred to score successes in the new field, and patents for new dyes discovered in the United States would be taken out with increased frequency.

Such, in its more essential features, it is claimed, would be the sequence of stages in the development of a national self-contained industry.

\section{THE PROBLEM IN ENGLAND AND FRANCE.}

Great Britain is a country in which the artificial dyestuff industry is much more dereloped than in the United States. It depends, however, upon Germany for its supply of colors almost as much as our own land. It has been cut off entirely for over seven months from this normal foreign supply. So severely have its textile and other industries been endangered that the British Government has deemed it an imperative duty to take the requisite steps to build up promptly a national coal-tar industry, depending upon national resources for its raw materials and covering the entire country's demand, or very nearly so.

On Norember 27, 1914, the President of the British Board of Trade, in presenting the subject before the House of Commons, said: "If we were to go on being dependent in the larger portion of our textile trade on supplies which Germany has the power to cut off whenever she pleases, we left the industry in a state of peril, and we should certainly be lacking in foresight if we were not prepared to take the steps necessary to put a stop to the entire dependence of what was, after all, the greatest of our manufacturing industries (i. e., textile manufactures), on commodities entirely under foreign control."

Since then the subject has been actively discussed by chemical interests, textile and dyers' associations, chambers of commerce, etc. Some have advocated a reversal of the traditional free-trade policy of the Kingdom, making a temporary exception in favor of artificial dyes. Some have proposed active cooperation with Switzerland, whose dye production could rapidly be enlarged, raw material being supplied from England. Others faror ample financial aid and close cooperation on the part of the Government, with the assurance of adequate protection against unfair competition after the war.

This last policy seems to have the majority of adherents, and has received Government sanction. On February 8 a definite plan was outlined by the Gorernment. It is based upon the formation of a national company with an initial capital of $\$ 10,000,000$. The Government is prepared to advance $\$ 5,000,000$ at the rate of $\$ 1$ for every $\$ 5$ subscribed by the public, and an additional $\$ 2,500,000$ at the rate of $\$ 1$ for every $\$ 4$ subscribed. Government advances receive 4 per cent interest. The Government will also grant $\$ 500,000$ for a research laboratory. Further details with regard to methods of protecting the new industry at the close of the war have not yet been receired.

Great Britain uses annually about 20,000 tons of artificial dyes, with an estimated value of $\$ 10,000,000$. The domestic manufacture of dyes ranges from 3,000 to 4,000 tons, one-half of which is exported. Nine-tenths of the consumption is of German origin. 
In France a similar movement has been inaugurated to permanently free the country from dependence for its dyestuff's upon Germany or any foreign source. A group of leading chemists has devoted itself for some time past to the details of the problem. Recent amnouncements in the press state that it has been satisfactorily solved, and that henceforth every phase of the industry can be established upon French soil, using exclusively French crudo materials. Coal-tar products are supplemented to some extent by residues from the beet-root sugar manufacture.

\section{SUMMARY.}

It appears that numerous American industries are dependent upon the use of dyestuffs and that artificial dyestuffs have displaced nearly all the natural dyestuffs; that the American consumption of artificial dyestuffs has attained an annual value of about $\$ 15,000,000$, and of this only about $\$ 3,000,000$ worth is supplied by domestic production, the rest coming mainly from Germany; that since the war in Europe German makers have not been able to supply the entire demand, and in consequence prices have risen from 25 to 50 per cent on such dyestuffs as can be delivered; that the supply of coal-tar dyestuffs throughout the world is completely dominated by the German industry, Germany furnishing in 1913 about 74 per cent of the total world's consumption; that the German dyestuff industry has been chiefly developed by the inventive power of German chemists, combined with a wealth of technical skill and keen business management scarcely equaled in the history of any other branch of manufacture; that in the United States the supply of coal tar is sufficient to provide all of the crudes required for the manufacture of the dyestuffs consumed in the country; that our manufacture of heavy chemicals is well developed and able to expand rapidly and supply all needed chemicals for the production of intermediates and their transformation into finished dyes; that 90 per cent of the dyes now consumed in the United States are patent-free, and that the remaining 10 per cent will soon be freed from patent restriction; that the advance of the American dyestuff industry, beyond certain limits, is persistently checked and prevented by the united action of German producers in underselling; and that the present crisis has evoked deep interest on the part of all concernedtar distillers, manufacturers of chemicals, manufacturers of dyestuffs, and users of the same, and economists in general-as to how the problem can be solved.

It appears, furthermore, that some American chemical works and American manufacturers of dyestuffs are ready to embark capital and experience in very materially enlarging the present limited scope of the American coal-tar chemical industry, using American crudes and intermediates, provided effective legislation is enacted to prohibit dumping and to prevent such action toward control of our markets by a foreign monopoly as is now prohibited to domestic industry.

Far-reaching efforts appear to have been made in England and France under Government auspices to free these countries from dependence on any foreign service for their supply of dyestuffs. 




Repiacement Microforth

found - ocle th 30875062

$9 \longdiv { 1 9 1 9 4 }$ 


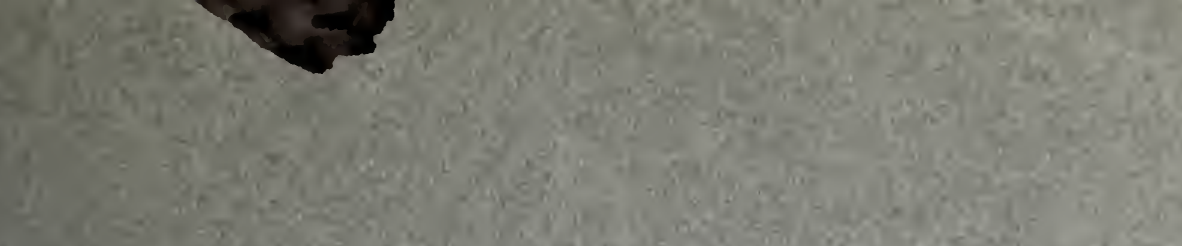

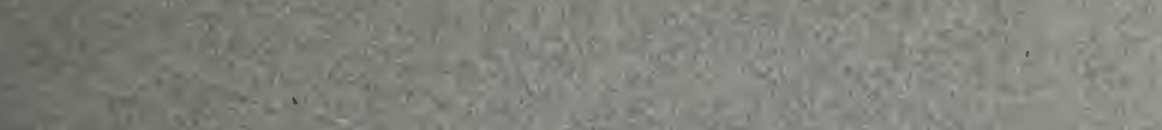

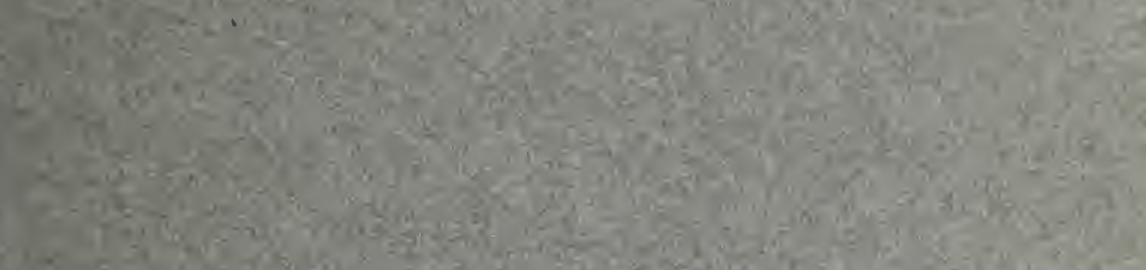

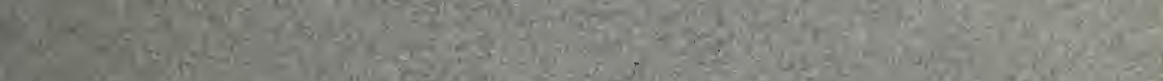

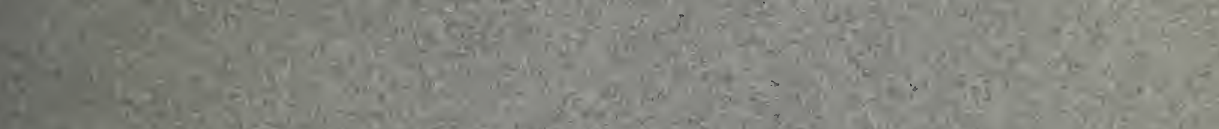

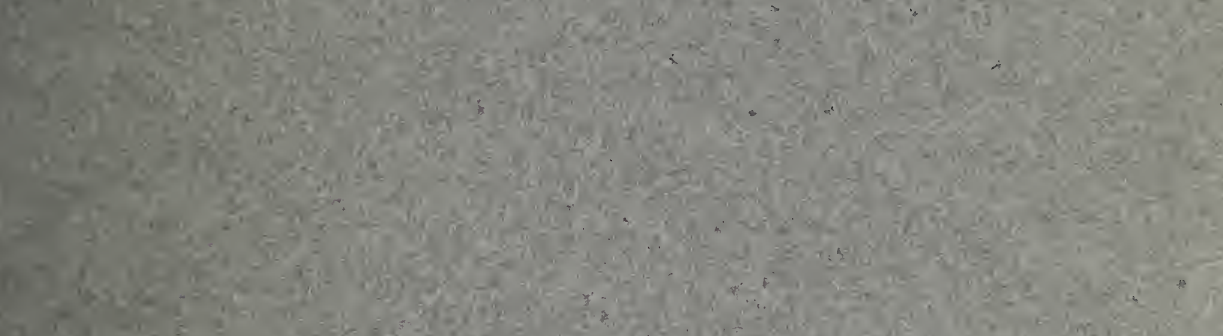

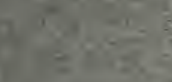

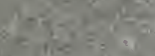
int

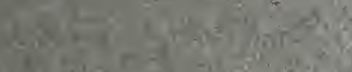
(2)

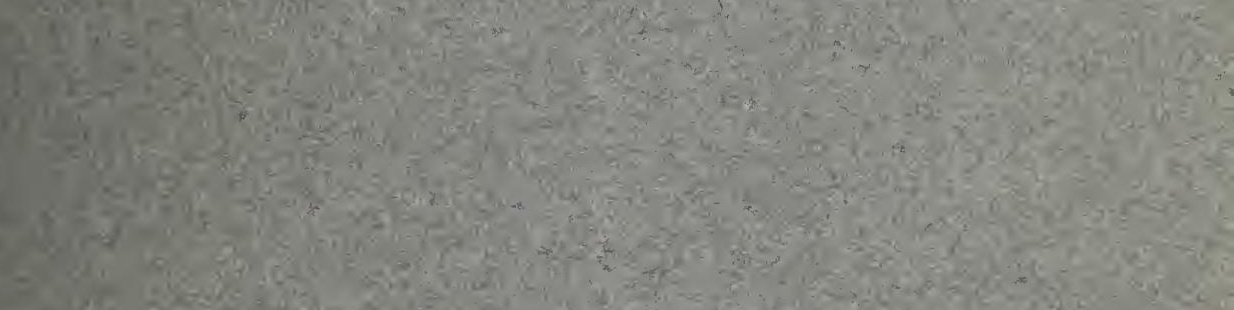

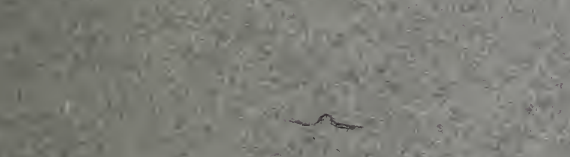
38,25 $\left.\sin ^{2}\right)^{2}$

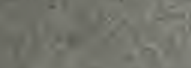

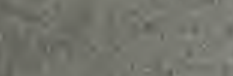

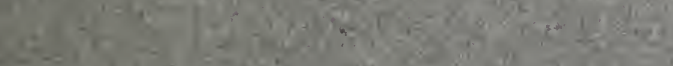

ix

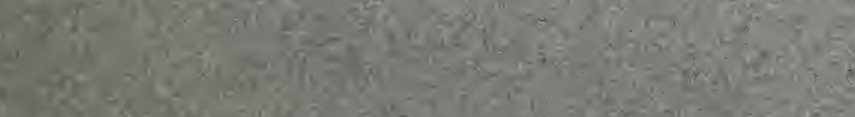
ing (6) 
SMITHSONIAN INSTITUTION LIBRARIES ||||||||||||||||||||||||||||||||||||||||||||||||||||||||||||||||||

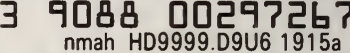

Dyestuffs for American textile and other 